\title{
Tracking and Visualizing Student Effort: Evolution of a Practical Analytics Tool for Staff and Student Engagement
}

\author{
Robin Nagy \\ Dean of Students, Redlands School \\ Sydney, Australia \\ rnagy@redlands.nsw.edu.au
}

\begin{abstract}
There is an urgent need for our educational system to shift assessment regimes from a narrow, high-stakes focus on grades, to more holistic definitions that value the qualities that lifelong learners will need. The challenge for learning analytics in this context is to deliver actionable asses sments of these hard-to-quantify qualities, valued by both educators and learners. This practitioner report contributes to this by documenting the iterative refinement of a practical approach for tracking student effort, deployed in successive versions over six years in secondary schools. This demonstrates how teachers can assess a student qual ity such as "effort" in a practical way, and the insights that visual analytics can provide as a basis for productive dialogue a mong staff and students. The engagement and professional development of teachers is critical to embedding and sustaining novel analytics of this sort.
\end{abstract}

Keywords: Effort, mindset, resilience, dispositional learning analytics, visualization, $21^{\text {st }}$ century skills

\section{INTRODUCTION: THE ACADEMIC OUTCOMES PARADOX}

Every school's goal includes delivering the best possible academic outcomes for their students; however, a direct focus on academic achievement often falls short of delivering consistent improvement for all students. Indeed, research studies have highlighted that "high-stakes" summative testing often has a negative effect on student motivation for learning, and can widen the gap between higher and lower achieving students (Harlen \& Deakin Crick, 2003). One reason for this is the systemically induced increase in student anxiety surrounding academic assessment, with a detrimental effect on performance in tests and examinations for a proportion of students (McDonald, 2001), as well as a generally adverse effect on student mental health and wellbeing. Another reason is that when a low-achieving student displays a dramatic improvement in effort, there is rarely an immediate corollary of academic achievement in assessments. This "lack of success" results in a de-motivational effect on students who have just invested a great deal of effort without seeing their diligence reflected in systemic value (academic achievement). Moreover, the short-term lack of causality between effort and achievement can compound students' sense of fixed mindset and belief that they lack ability, and strengthen some students' belief that diligence has no effect on "smartness"; they "lose confidence in their own capacity to learn" (Black \& Wiliam, 1998; Harlen \& Deakin Crick, 2003, p. 18). 
(2016). Tracking and visualizing student effort: Evolution of a practical analytics tool for staff and student engagement. Journal of Learning Analytics, 3(2), 165-193. http://dx.doi.org/10.18608/jla.2016.32.8

Driven by sociological expectation, schools tend to dwell on quantifying success in terms of academic results al one. The result of this unidirectional focus on achievement is to undermine the development of academic curiosity, persistence, and intellectual risk-taking, all of which are skills, identified in Costa and Kallick's (2009) Habits of Mind, necessary to be able to develop into independent lifelong learners and to be able to tackle harder, more challenging problems. Moreover, Kellaghan, Madaus, and Raczek (1996) conclude from their research that students motivated by high-stakes assessment are likely to have performance rather than learning goals, and extrinsic rather than intrinsic motivation, leading them to become "shallow" learners and develop superficial learning styles such as rote learning. When a school does systemically report on effort, it is rarely more than a single five-point scale with little to no objectivity, and there is usually a high correlation to students' academic achievement due to the way in which teachers are forced to report. For example, many schools traditionally report academic achievement on a 5-point scale from $A$ (best) to $E$ (worst) and effort on a similar scale from 1 (best) to 5 (worst). It is easy for a teacher to justify awarding a student A-1, B-2, C-3 and so on, but not so easy to justify say an E-1 due to the inherent presumption that a student could have scored better in assessments with more effort.

Carol Dweck (2006) makes clear that focusing on praising intelligence and ability does not create success and may in fact do the opposite. ${ }^{1}$ Other notable research on success by Angela Duckworth (Perkins-Gough, 2013) shows that "grit" (or persistence) is the single biggest indicator of success in the long term, much more so than academic potential. Given the focus and reporting on academic results, it seems unsurprising that schools have a tendency to foster those students who already have a growth mindset and selfmotivation, whereas those with a "fixed mindset" who lack this intrinsic perseverance are often convinced that they are failuresand lose all motivation to try (Dweck, 2006). This is summed up well by Schunk (1991) who concludes, "learners who attribute success to effort, and who perceive ability to be changeable and controllable are likely to deal with failure constructively, and to persevere with the learning task ... whereas learners who attribute failure to ability, which they perceive as stable and uncontrollable, are likely to respond negatively to summative assessment." The moderating influence on this concerning picture is good teachers, who instinctively know the importance of building confidence and encouraging effort and perseverance, but often they are not always helped systemically by school structures. It could be argued that much of the value-added effect they have on "less able" students is in spite of, rather than because of, school-wide systems.

The problem, concisely, is a paradox; rewarding academic success does not necessarily motivate all students to achieve academic success. To use Andrew Martin's (2010) terminology, this system benefits those students who have an innate "academic buoyancy." In order to create an environment where every student maximizes their potential, schools need to shift the "success-focus" away from achievement

\footnotetext{
${ }^{1}$ Recently, Dweck has also criticized the misinterp retation of her work, which has led to students being offered empty praise for "just trying" without a ta ngible link to developing the underlying competencies for learning. Dweck uses the a nalogy of the bra in as a muscle, which can be strengthened and de veloped through a ppropriate academic exercise and persistence. Reporting that simply praises effort falls short of developing a growth mindset unless it specifically tracks and highlights student progres $s$ and improvement over time.
} 
(2016). Tracking and visualizing student effort: Evolution of a practical analytics tool for staff and student engagement. Journal of Learning Analytics, 3(2), 165-193. http://dx.doi.org/10.18608/jla.2016.32.8

alone, onto more nurturing and motivational indicators such as effort and incremental achievement. Indeed, the Hobsons report into student feedback and progressive reporting showed that Australian parents supported this notion, stating

Parents prefer reporting based on their child's progression rather than measurement against a benchmark (despite popular belief). This reflects the need for progressive reporting. (Hobsons, 2014, p. 6)

The report finds that parents are primarily interested in hearing about the development and progression of their child before hearing about how they compare to others. Although rankings are viewed as important, it is not parents' principal concern. This concurs with my own anecdotal experience that most parents' overriding wish is that their child is trying as hard as they can, and this would seem to be not only an instinctive approach to success, but also one backed up by Duckworth's sound academic research (Perkins-Gough, 2013).

We can learn much from techniques used by sportsmen and -women to improve performance. Sports psychologists have long known that a direct performance focus often has a paradoxical effect on achievement and that in order to improve performance, it is better to employ an indirect focus that often concentrates on process rather than outcome. For instance, Jackson (2014) states, "...explicit monitoring of motor skills has been shown to have a detrimental effect on skilled performers." Smith and Kays (2010) advise, "If you focus on outcomes (things you have no control over), you're creating unnecessary anxiety. Focus on the process and you increase the likelihood of positive results happening."

In education, a focus on student effort rather than achievement is analogous to this indirect focus on process rather than outcome. It ensures that the systemic value is placed on the underlying characteristics of a successful student rather than the outcomes themselves. Indeed, there is plenty of evidence to suggest that a focus on summative testing as an outcome-based reward system has a detrimental effect on motivation for learning and inhibits the practice of formative assessment (Black \& Wiliam, 1998 cited in Harlen \& Deakin Crick, 2003 p. 170). Once students feel that their diligence and attitude are being recognized and rewarded in their own right, their anxiety surrounding examinations is reduced, and the school "success-focus" implicitly encourages a "growth mindset" mentality in its students. Without an explicit school-wide emphasis on process, students deduce that although effort may be encouraged, it is achievement that counts; assessments intended as formative are nevertheless interpreted by students as purely summative in purpose (Pollard, Triggs, Broadfoot, McNess, \& Osborn, 2000).

The research by Dweck and Duckworth has already been acknowledged as the rationale for focusing on effort. In the context of Learning Analytics, the approach described next is a form of Dispositional Learning Analytic (Buckingham Shum \& Deakin Crick, 2012; Deakin Crick, Huang, Ahmed-Shafi, \& Goldspink, 2015), but using teacher observation rather than student self-report as in their work. Such analytics are designed explicitly to provoke change in students, by providing staff with deeper insight into a student's progress, leading to more effective coaching conversations around the visual analytic. In the context of design- 
(2016). Tracking and visualizing student effort: Evolution of a practical analytics tool for staff and student engagement. Journal of Learning Analytics, 3(2), 165-193. http://dx.doi.org/10.18608/jla.2016.32.8

based educational research, this approach is an example of an Improvement Science methodology (Bryk, 2015) in which the emphasis is on targeting an issue identified as a key driver for success, using analytics to track variables as thoroughly grounded in research as possible, but equally important, rendered in a practical form - for use by practitioners (not researchers) in authentic contexts (not artificial settings). ${ }^{2}$

The case study context for this work is now introduced, before a documentation of the iterations leading to the effort-tracking tool.

\section{CASE STUDY 1: CRANBROOK SCHOOL, SYDNEY}

Students' academic effort is celebrated at Cranbrook through a termly "Headmaster's List of Outstanding Academic Attitude," which specifically recognizes attitude and effort in class rather than achievement. Originally this was based on students' termly effort grades ( 1 to 5 scale) reported by teachers in each subject, with the top $10 \%$ or so students in the school being included on the list, leading to House points and privileges for senior students. The idea behind this system is that it runs alongside the annual academic prizes but includes many hard-working students who may not be top achievers and would otherwise go unrecognized, Cranbrook school being non-selective academically.

While at Cranbrook, the author developed a quantitative measure of studenteffort and conducted schoolwide "effort-tracking" over a period of five years. This was based on the aggregated "effort score" for each student, calculated by averaging and scaling their effort grades across all subjects. At the start of a new term, students received individual feedback via their pastoral tutor on their current effort percentile within the year-group and within the whole school, as well as the breakdown of their effort score over their academic subjects and whether or not there was an improvement or decline since the previous term. It also highlighted if this was the student's Personal Best effort score to date.

As well as identifying students on the "Headmaster's List of Outstanding Academic Attitude," the effort tracking program also highlighted students at the bottom of the effort-range, as well as those who had shown notable improvement or dramatic decline in effort over the past reporting period. This allowed pastoral carers to have focused conversations with allstudents, which sometimes exposed other factors affecting student motivation, such as family issuesand other external influences. Nevertheless, there was initially a high correlation between academic achievement and effort scores due to the way in which effort was graded. Over time, the system for measuring effort became better defined, with two attitude indicators recorded by academic subjects for each student, every term - one based on diligence and the other on behaviour. This produced a better measure of effort and a weaker correlation with academic achievement.

\footnotetext{
${ }^{2}$ For the practitioner-researcher deve lopment program around this approach, see the Ca rnegie Foundation for the Advancement of Tea ching: $\underline{\text { http://www.carnegiefoundation.org }}$
} 
(2016). Tracking and visualizing student effort: Evolution of a practical analytics tool for staff and student engagement. Journal of Learning Analytics, 3(2), 165-193. http://dx.doi.org/10.18608/jla.2016.32.8

This was progress, but the attitude grades were limited in their scope and subjective in their distribution. Clearly, there are difficulties in quantifying student effort consistently across all teachers and subjects. One can be more confident in teachers' grading across semesters within particular cohorts. Assuming teachers are consistent in their own reporting, then "relative effort" for a given cohort is meaningful and valid. A next step would be a consistent and accurate method to gauge and quantify student effort and attitude on a whole (secondary) school basis. This is particularly important for tracking student effort on a term-by-term basis over several years, as well as providing visibility to parents that students with outstanding effort be accurately identified.

\section{CASE STUDY 2: REDLANDS SCHOOL}

At Redlands School, the author wanted to design such a system: capable of student tracking, incorporating reliable effort indicators in all subjects and quick and easy for teachers to grade, whilst being as consistent and objective as possible across all students and all subjects.

\subsection{Prototype 1: Effort Criteria, Grading Interface and Output}

The initial year-long effort tracking pilot originally had four criteria (below), each of which had a 5-point scale ( 1 to 5 respectively for Unsatisfactory, Fair, Good, Very Good, and Outstanding) with the weighting deliberately skewed to quantify four level s of "satisfactory" rather than defining levels of "unsatisfactory":

- Attitude and Behaviour

- Diligence and Application

- Engagement and Focus

- Persistence and Determination

Using four separate criteria and averaging effort scores across subjects ensured additional safeguards against any individual anomalies in reporting and encouraged a better spread of data (particularly with a 5-point scale). To ensure as much consistency and objectivity as possible, the teacher grading was via four separate input screens, one for each criterion, with the whole class graded on each screen using quick and easy to use radio button selection as illustrated in Figure 1. This forced teachers to apply each criterion to each student in turn, ensuring a better relative grading and consistency within the class. Anecdotal evidence suggests that systems that force teachers to report on a single student at a time using different subjective measures tend to elicit a high correlation between these grades. This is borne out by my analysis of the original Redlands "Attitude to Learning" grades, which had a much greater correlation between effort and achievement (0.84) than the results of the effort-tracking pilot (0.62), partly because both attitude and achievement were recorded on the same screen for a sing le student. This was also true of the Cranbrook system. 
(2016). Tracking and visualizing student effort: Evolution of a practical analytics tool for staff and student engagement. Journal of Learning Analytics, 3(2), 165-193. http://dx.doi.org/10.18608/jla.2016.32.8

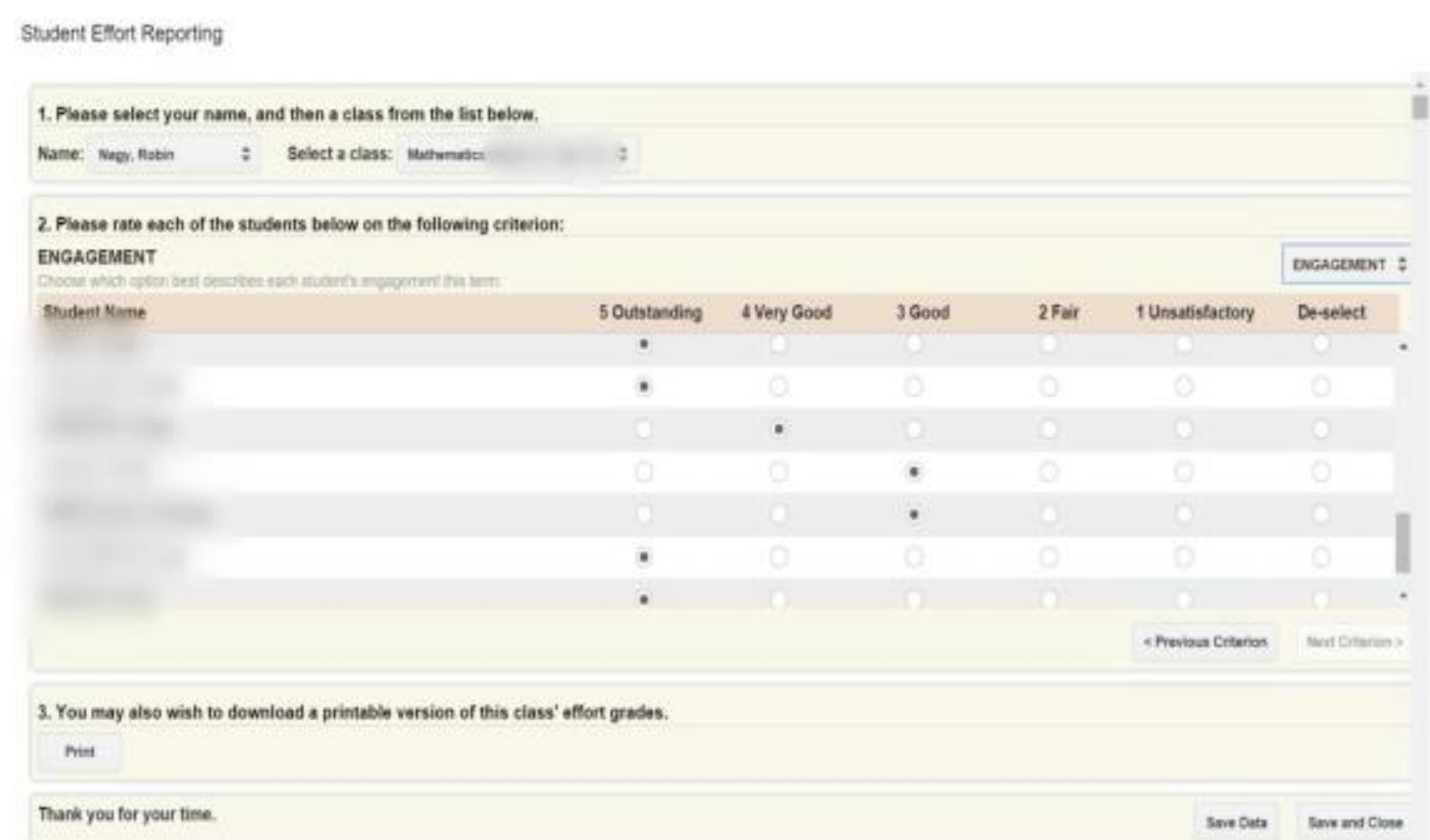

Figure 1: Teacher input screen for effort grading on a given criterion (Engagement). Grading all students on a single criterion at a time encourages the teacher to ensure relative consistency between students.

Once all students had been graded, their effort scores for each subject (from 4 to 20) would be aggregated over all subjects, including pastoral care period, and averaged over the total number of subjects. This overall average "Effort Score" would then be used as the basis for ranking and tracking students' effort as well as for obtaining students' effort percentiles within their year-group and within the whole secondary school.

Initial teacher consultation led to the creation of an extensive rubric for each criterion, with twenty separate descriptors, one for every grade in each criteria (see Figure 2). The criteria headings were also condensed to single word descriptors to simplify their interpretation:

- Behaviour

- Diligence

- Engagement

- Persistence

The output from this process was collated into Figures $3 \mathrm{a}$ and $3 \mathrm{~b}$, displaying students' individual effort grades across their subjects as well as groups of students' overall average effort grades. 


\section{JOURNAL OF LEARNING ANALYTICS S\&LAR}

(2016). Tracking and visualizing student effort: Evolution of a practical analytics tool for staff and student engagement. Journal of Learning Analytics, 3(2), 165-193. http://dx.doi.org/10.18608/jla.2016.32.8

\section{Effort Tracking Pilot - Criteria Rubric}

Behaviour- Appropriate conduct and positive attitude that is conducive to learning, both for self and peers

Diligence- Due care and rigour applied in all learning situations and appropriate completion of set work

Engagement- The focus and active participation demonstrated by a student to maximise their learning potential.

Persistence- The resilience, motivation and determination demonstrated by a student leading them to take pride in, and responsibility for, their learning.

\begin{tabular}{|c|c|c|c|c|c|}
\hline & 5 Outstanding & 4 VeryGood & 3 Good & 2 Fair & 1 Unsatisfactory \\
\hline Behaviour & $\begin{array}{l}\text { Always conducts themselves } \\
\text { appropriately inclass, which helps } \\
\text { maximise productivityand supports } \\
\text { a safe and engaging learning } \\
\text { environment for others. } \\
\text { - Avoids distraction } \\
\text { - Is sensitive to the vi ews of } \\
\text { peers and responds } \\
\text { accordingly } \\
\text { - Engages with te achers and } \\
\text { peers in a respectful and } \\
\text { considerate manner } \\
\text { - Neverwilfully disrupts the } \\
\text { learning of others } \\
\text { - Displays a positive attitude } \\
\text { to learning at all times. }\end{array}$ & 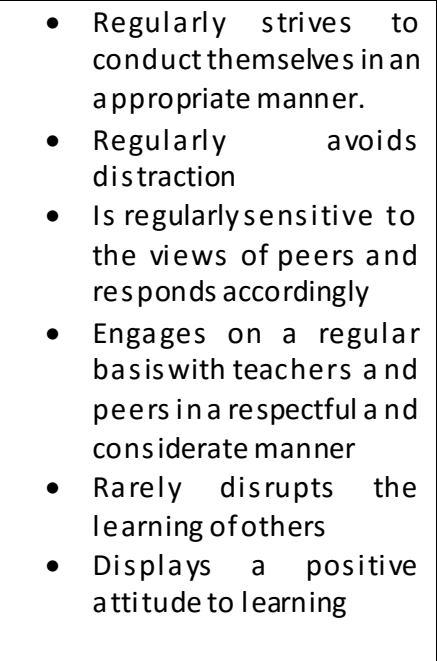 & $\begin{array}{l}\text { - Mostly strives to } \\
\text { conduct themselves in } \\
\text { an appropriate manner. } \\
\text { - Mostly avoids } \\
\text { distraction } \\
\text { - Is mostly sensitive to } \\
\text { the views of peers and } \\
\text { responds accordingly } \\
\text { - Mostly engages with } \\
\text { teachers andpeers in a } \\
\text { respectful and } \\
\text { considerate manner } \\
\text { - Sometimes disrupts the } \\
\text { learning ofothers } \\
\text { - Usually displays a } \\
\text { positive attitude to } \\
\text { learning }\end{array}$ & $\begin{array}{l}\text { - Occasionally strives to } \\
\text { conduct themselves in an } \\
\text { appropriate manner. } \\
\text { - Occasionally avoids } \\
\text { distraction } \\
\text { - Is occasionallys ensitive to } \\
\text { the views of peers and } \\
\text { responds accordingly } \\
\text { - Occasionallye ngages with } \\
\text { teachers and peers in a } \\
\text { respectfuland considerate } \\
\text { manner } \\
\text { - Regularly disrupts the } \\
\text { learning ofothers } \\
\text { - Sometimes displays a } \\
\text { positive attitude tolearning }\end{array}$ & $\begin{array}{l}\text { - Rarely strives to conduct } \\
\text { themselves in a nappropriate } \\
\text { manner. } \\
\text { - Rarelya voids distraction } \\
\text { - Is seldom sensitive to the } \\
\text { views of peers and respon ds } \\
\text { accordingly } \\
\text { - Ra relyengages with teachers } \\
\text { and peers in a respectful and } \\
\text { considerate manner } \\
\text { - Constantly dis rupts the } \\
\text { learning of others } \\
\text { - Seldomdisplays a positive } \\
\text { attitude to learning. }\end{array}$ \\
\hline Diligence & $\begin{array}{l}\text { Is extremely conscientious and } \\
\text { consistently puts much effort and } \\
\text { care into both classand homework. } \\
\text { - Concerted effort is applied in } \\
\text { everysituation } \\
\text { - Shows a genuine commitment to } \\
\text { independent learning, with the } \\
\text { creation of a study plan that } \\
\text { supports their learning. } \\
\text { - Application in class supports } \\
\text { their understanding and } \\
\text { maximises their learning } \\
\text { outcomes. }\end{array}$ & $\begin{array}{l}\text { Regularly shows that effort and } \\
\text { ca re is put into both cl ass and } \\
\text { homework. } \\
\text { - Effort is applied regularly in } \\
\text { situations } \\
\text { - Regularly shows a } \\
\text { commitment to independent } \\
\text { learning that supports their } \\
\text { learning. } \\
\text { - Regular application in class } \\
\text { supports their learning } \\
\text { outcomes. }\end{array}$ & $\begin{array}{l}\text { Mostlys hows that effort and } \\
\text { care is put into both class and } \\
\text { homework. } \\
\text { - Effort is usually a pplied in } \\
\text { situations } \\
\text { - On most occasions they } \\
\text { show a commitment to } \\
\text { independent learning that } \\
\text { supports theirlearning. } \\
\text { - Application inclass usually } \\
\text { supports their learning } \\
\text { outcomes. }\end{array}$ & $\begin{array}{l}\text { Occasionally shows that effort } \\
\text { and care is put into both cl ass } \\
\text { and homework. } \\
\text { - Effort is not always applied in } \\
\text { situations } \\
\text { - Commitment to independent } \\
\text { learning is sporadic } \\
\text { - Occasionally applies } \\
\text { thems elves in class }\end{array}$ & $\begin{array}{l}\text { Rarelyshows that effortandcare } \\
\text { is put into both class and } \\
\text { homework. } \\
\text { - Effort is rarely applied in } \\
\text { situations } \\
\text { - Commitment to independent } \\
\text { learning is seldompresent } \\
\text { - Rarelyapplies themselves in } \\
\text { class }\end{array}$ \\
\hline
\end{tabular}

Figure 2 (part 1): Initial effort criteria rubric. 


\section{JOURNAL OF LEARNING ANALYTICS S@LAR}

(2016). Tracking and visualizing student effort: Evolution of a practical analytics tool for staff and student engagement. Journal of Learning Analytics, 3(2), 165-193. http://dx.doi.org/10.18608/jla.2016.32.8

\begin{tabular}{|c|c|c|c|c|c|}
\hline & 5 Outstanding & 4 Very Good & 3 Good & 2 Fair & 1 Unsatisfactory \\
\hline Engagement & $\begin{array}{l}\text { Always proactively strives for a high level of } \\
\text { personal focus and involvement in class. This } \\
\text { may include some or all of the following: } \\
\text { - Appropriately participates in class } \\
\text { discussions and asks questions. } \\
\text { - Actively listens to instruction and } \\
\text { follows all directions in class. } \\
\text { - Instigates class discussion and } \\
\text { listens and responds to the views of } \\
\text { others. } \\
\text { Takes detailed and effective notes, } \\
\text { completes thorough research and } \\
\text { works collaboratively to use class } \\
\text { time most effectively. } \\
\text { Works independently and } \\
\text { collaboratively to maximise } \\
\text { potential and is always on task. }\end{array}$ & $\begin{array}{l}\text { Regularly strives for } \\
\text { personal focus and } \\
\text { involvement in class. } \\
\text { - } \quad \text { Participates in class } \\
\text { discussions and asks } \\
\text { questions. } \\
\text { - } \quad \text { Regularly listens to } \\
\text { instructions. } \\
\text { - Is involved in class } \\
\text { discussions } \\
\text { - } \quad \text { Takes very good notes. } \\
\text { Regularly works } \\
\text { independently and } \\
\text { collaboratively and is } \\
\text { generally on task. }\end{array}$ & $\begin{array}{l}\text { Mostly strives for personal } \\
\text { focus and involvement in } \\
\text { class. } \\
\text { - } \quad \text { Sometimes } \\
\text { participates in class } \\
\text { and asks questions } \\
\text { - Mostly listens to } \\
\text { instructions and is } \\
\text { involved in class } \\
\text { discussions } \\
\text { - Takes good notes. } \\
\text { - Mostly works } \\
\text { independently and } \\
\text { collaboratively and is } \\
\text { usually on task. }\end{array}$ & $\begin{array}{l}\text { Occasionally strives for } \\
\text { personal focus and } \\
\text { involvement in class. } \\
\text { - Occasionally participates } \\
\text { in class and asks } \\
\text { questions } \\
\text { - Sometimes listens to } \\
\text { instructions and is } \\
\text { involved in class } \\
\text { discussions } \\
\text { - Takes notes when } \\
\text { instructed. } \\
\text { - Works when directed but } \\
\text { easily drifts off task. }\end{array}$ & $\begin{array}{l}\text { Rarely strives for personal } \\
\text { focus and involvement in } \\
\text { class. } \\
\text { - } \quad \text { Rarely participates } \\
\text { unless directly asked } \\
\text { to } \\
\text { - } \quad \text { Is a passive learner } \\
\text { - } \quad \text { Does not demonstrate } \\
\text { good listening skills } \\
\text { - } \quad \text { Does not take } \\
\text { adequate notes. } \\
\text { - Appears to take little } \\
\text { pride or interest in } \\
\text { class. } \\
\text { Is often off task. }\end{array}$ \\
\hline Persistence & $\begin{array}{l}\text { Always demonstrates the necessary } \\
\text { perseverance in order to develop deep } \\
\text { interest and creativity in their learning both in } \\
\text { and out of school. } \\
\text { - Takes a great deal of pride in their } \\
\text { - Tork. } \\
\text { - Takes calculated risks to advance } \\
\text { - Showns responsibility for own actions } \\
\text { - and accompanying consequences. } \\
\text { - Always demonstrates determination } \\
\text { and resilience. } \\
\text { - Reacts well to criticism and sees } \\
\text { mistakes as opportunities to learn. } \\
\text { - Sees difficulties as challenges to be } \\
\text { overcome rather than obstacles. } \\
\text { Is always self-motivated and works } \\
\text { independently. }\end{array}$ & $\begin{array}{l}\text { Regularly demonstrates the } \\
\text { necessary perseverance in } \\
\text { order to develop interest } \\
\text { and creativity in their } \\
\text { learning both in and out of } \\
\text { school. } \\
\text { - } \quad \text { Takes pride in their } \\
\text { work. } \\
\text { - } \quad \text { often takes risks and } \\
\text { - } \quad \text { Deminks laterally. } \\
\text { determination and } \\
\text { - } \quad \text { Ovesilience. } \\
\text { - Regularly works } \\
\text { independently }\end{array}$ & $\begin{array}{l}\text { Mostly demonstrates the } \\
\text { necessary perseverance in } \\
\text { order to develop interest } \\
\text { and some creativity in their } \\
\text { learning both in and out of } \\
\text { school. } \\
\text { - Takes some pride in } \\
\text { their work. } \\
\text { - Takes some risks and } \\
\text { thinks laterally. } \\
\text { - Sometimes } \\
\text { demonstrates } \\
\text { determination and } \\
\text { resilience. } \\
\text { - Sometimes overcomes } \\
\text { challenges } \\
\text { - Mostly works } \\
\text { independently }\end{array}$ & $\begin{array}{l}\text { Occasionally demonstrates } \\
\text { perseverance in order to } \\
\text { develop some interest in their } \\
\text { learning both in and out of } \\
\text { school. } \\
\text { - Takes occasional pride in } \\
\text { their work. } \\
\text { - Occasionally overcomes } \\
\text { challenges and shows } \\
\text { determination. } \\
\text { - Sometimes works } \\
\text { independently. }\end{array}$ & $\begin{array}{l}\text { Rarely demonstrates } \\
\text { perseverance in order to } \\
\text { develop interest in their } \\
\text { learning both in and out of } \\
\text { school. } \\
\text { - Takes no pride in their } \\
\text { work. } \\
\text { - Gives up easily. } \\
\text { - Does not demonstrate } \\
\text { independent work } \\
\text { habits. } \\
\text { Needs constant } \\
\text { directions. }\end{array}$ \\
\hline
\end{tabular}

Figure 2 (part 2): Initial effort criteria rubric. 


\begin{tabular}{|c|c|c|c|c|c|c|c|c|c|c|}
\hline Name & Year & Tutor & Gender & CLASS_NAME & Teacher & BEHAVIOUR & DILIGENCE & ENGAGEMENT & PERSISTENCE & SUM \\
\hline STUDENT NAME & Year 08 & Tutor Name & $F$ & History (Core) Year $8^{*}$ & Teacher 1 & 4 & 4 & 3 & 3 & 14 \\
\hline STUDENT NAME & Year 08 & Tutor Name & F & Mathematics Strand "* Year $8^{*}$ & Teacher 2 & 4 & 4 & 3 & 3 & 14 \\
\hline STUDENT NAME & Year 08 & Tutor Name & $\mathrm{F}$ & Visual Arts (Elective) Year $8^{*}$ & Teacher 3 & 5 & 4 & 4 & 4 & 17 \\
\hline STUDENT NAME & Year 08 & Tutor Name & $F$ & Christian Studies Year 8 * & Teacher 4 & 3 & 3 & 3 & 3 & 12 \\
\hline STUDENT NAME & Year 08 & Tutor Name & $\mathrm{F}$ & English Year $8^{*}$ & Teacher 5 & 4 & 4 & 4 & 4 & 16 \\
\hline STUDENT NAME & Year 08 & Tutor Name & $F$ & French Year $8^{*}$ & Teacher 6 & 5 & 4 & 4 & 5 & 18 \\
\hline STUDENT NAME & Year 08 & Tutor Name & $F$ & Geography (Core) Year $8^{*}$ & Teacher 7 & 4 & 4 & 4 & 4 & 16 \\
\hline STUDENT NAME & Year 08 & Tutor Name & $F$ & Science Year $8^{*}$ & Teacher 8 & 5 & 4 & 4 & 4 & 17 \\
\hline STUDENT NAME & Year 08 & Tutor Name & $F$ & Technology Year $8^{*}$ & Teacher 9 & 4 & 4 & 4 & 5 & 17 \\
\hline STUDENT NAME & Year 08 & Tutor Name & $F$ & Tutor $8^{* *}$ & Teacher 10 & 5 & 3 & 3 & 4 & 15 \\
\hline
\end{tabular}

Figure 3a: Initial effort tracking output (single student).

\begin{tabular}{|c|c|c|c|c|c|c|c|c|c|c|c|}
\hline$\sum_{\frac{\pi}{\pi}}^{\frac{\nu}{2}}$ & 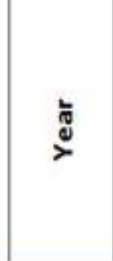 & 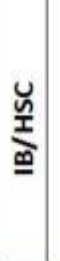 & $\begin{array}{l}\text { پั } \\
\stackrel{0}{x}\end{array}$ & 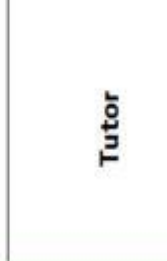 & 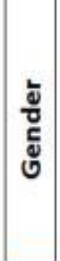 & ڤั้ & 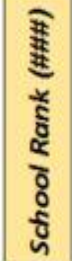 & & 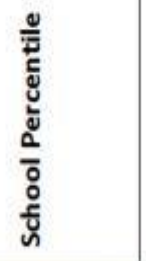 & 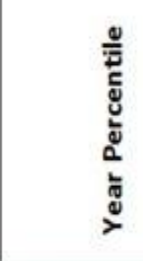 & \\
\hline STUDENT 1 & Year 10 & & $* * * * *$ & Tutor Name & $M$ & 18.8 & 34 & & $96 \%$ & & $93 \%$ \\
\hline STUDENT 2 & Year 10 & & $* * * * *$ & Tutor Name & $M$ & 18.3 & 79 & & $91 \%$ & & $86 \%$ \\
\hline STUDENT 3 & Year 10 & & $* * * * *$ & Tutor Name & $F$ & 18.0 & 101 & & $89 \%$ & & $82 \%$ \\
\hline STUDENT 4 & Year 10 & & $* * * * *$ & Tutor Name & $F$ & 17.6 & 155 & & $83 \%$ & & $77 \%$ \\
\hline STUDENT 5 & Year 10 & & $* * * * *$ & Tutor Name & $M$ & 17.2 & 221 & & $75 \%$ & & $73 \%$ \\
\hline STUDENT 6 & Year 10 & & $* * * * *$ & Tutor Name & $F$ & 17.1 & 250 & & $72 \%$ & & $71 \%$ \\
\hline STUDENT 7 & Year 10 & & $* * * * *$ & Tutor Name & M & 17.0 & 254 & & $71 \%$ & & $71 \%$ \\
\hline STUDENT 8 & Year 10 & & $* * * * *$ & Tutor Name & $M$ & 16.9 & 277 & & $69 \%$ & & $67 \%$ \\
\hline STUDENT 9 & Year 10 & & $* * * * *$ & Tutor Name & $F$ & 16.8 & 294 & & $67 \%$ & & $66 \%$ \\
\hline STUDENT 10 & Year 10 & & $* * * * *$ & Tutor Name & $M$ & 16.6 & 328 & & $63 \%$ & & $63 \%$ \\
\hline STUDENT 11 & Year 10 & & $* * * * *$ & Tutor Name & $F$ & 16.4 & 357 & & $60 \%$ & & $61 \%$ \\
\hline STUDENT 12 & Year 10 & & $* * * * *$ & Tutor Name & $F$ & 15.9 & 444 & & $50 \%$ & & $54 \%$ \\
\hline STUDENT 13 & Year 10 & & $* * * * *$ & Tutor Name & $M$ & 15.9 & 446 & & $50 \%$ & & $53 \%$ \\
\hline STUDENT 14 & Year 10 & & $* * * * *$ & Tutor Name & $M$ & 15.0 & 590 & & $33 \%$ & \begin{tabular}{|l|} 
\\
\end{tabular} & $42 \%$ \\
\hline STUDENT 15 & Year 10 & & $* * * * *$ & Tutor Name & $F$ & 14.9 & 622 & - & $30 \%$ & \begin{tabular}{|l|} 
\\
\end{tabular} & $38 \%$ \\
\hline STUDENT 16 & Year 10 & & $* * * * *$ & Tutor Name & $M$ & 13.8 & 714 & $\square$ & $19 \%$ & $\square$ & $24 \%$ \\
\hline STUDENT 17 & Year 10 & & $* * * * *$ & Tutor Name & $M$ & 12.9 & 783 & $\square$ & $12 \%$ & $\square$ & $15 \%$ \\
\hline STUDENT 18 & Year 10 & & $* * * * *$ & Tutor Name & $M$ & 12.2 & 809 & & $9 \%$ & & $10 \%$ \\
\hline
\end{tabular}

Figure 3b: Initial effort tracking output (tutor group summary).

Following the first term of effort grading, all teachers were consulted via a survey and through direct discussions to determine their reactions to the initial process and structure of the effort-tracking pilot. There was widespread positive reaction for the ease of data entry via the radio-button screens and the efficiency and speed of the reporting input. Some of the critical feedback included reducing the number of effort criteria, developing departmental interpretations of the effort rubric, and simplifying the size and extent of the rubric. It was envisaged that with further refinement, pastoral tutors would be able to conduct beginning of term conversations with each student in their tutor group, based on the effort data from the previous term.

Applying correlation analysis between each pair of criteria, the correlation coefficients ranged between 0.65 and 0.77 (see Table 1) affirming a predictable positive correlation between each pair 
(2016). Tracking and visualizing student effort: Evolution of a practical analytics tool for staff and student engagement. Journal of Learning Analytics, 3(2), 165-193. http://dx.doi.org/10.18608/jla.2016.32.8

but highlighting that teachers were able to differentiate between the criteria. Nevertheless, on further consultation and discussion, it became apparent that the similarity between Diligence and Persistence was most significant, these being the strongest correlated of the criteria, and that, in the words of one teacher, "It is possible to think of a student who is diligent and not persistent, but not of one who is persistent and not diligent." For these reasons and based on the statistical evidence, it was decided to reduce the number of criteria to three, absorbing Persistence within Diligence and to a lesser extent within the other two criteria. It was hoped that this would not significantly affect the quality and distribution of effort grades and would have the benef it of reducing teachers' reporting overheads by $25 \%$.

Table 1: Correlation analysis of criteria pairs.

\begin{tabular}{|l|l|}
\hline Pearson's Correlation Coefficient for: & \\
\hline Diligence and Persistence & 0.77 \\
\hline Diligence and Engagement & 0.76 \\
\hline Engagement and Persistence & 0.75 \\
\hline Behaviour and Diligence & 0.71 \\
\hline Behaviour and Engagement & 0.67 \\
\hline Behaviour and Persistence & 0.65 \\
\hline
\end{tabular}

This established the rationale and requirements for the next design iteration.

\subsection{Prototype 2: Disciplinary Tuning, Training, Grading Interface, and Output}

The effort rubric was condensed to a more usable form (see Figure 4a) and a whole-staff consultation process ensued during a Professional Development day, with individual departments creating their own department-specific interpretations of the effort rubric, including a pastoral interpretation for tutors (see Figure 4b). The "Effort Score" was scaled from the original (4 to 20) to a scale of 20 to 100, so that the three-criterion score could be compared directly to the four-criterion score and give a percentage-feel that "perfect effort" equated to a score of 100, rather than 20 or 15.

In fact, the reduction from four to three criteria saw very little change in the distribution of overall effort scores with the mean unchanged at 78.4 and the standard deviation slightly incre asing from 10.6 to 11.4 , possibly indicating that teachers were spending more time discriminating between students on each criteria because of the reduced overhead.

In addition to the refinement of the effort reporting structure and process, teachers and pastoral carers were trained in the interpretation of the resulting summary data. The purpose of this was to help them to understand how to read the summary data and to be able to recognize significant patterns and scores for individual students. For pastoral tutors, it also informed and provided a scaffold for their one-on-one interviews with each of their tutees at the beginning of every term, using the effort tracking data recorded at the end of the previous term to help motivate and encourage student focus and diligence in the term ahead. 


\begin{tabular}{|c|c|c|c|c|c|}
\hline \multicolumn{6}{|c|}{ Effort Tracking Rubric } \\
\hline \multirow[b]{3}{*}{ 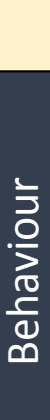 } & 5- Outstanding & 4- Very Good & 3- Good & 2- Fair & 1- Unsatisfactory \\
\hline & \multicolumn{5}{|c|}{ Classroom Conduct and Attitude, Politeness and Respect, Consideration for the Learning of Others } \\
\hline & $\begin{array}{l}\text { Proactively models positive } \\
\text { classroom behaviour and attitude at } \\
\text { all times, avoids distraction and } \\
\text { shows respect and consideration for } \\
\text { others. Is polite and courteous at all } \\
\text { times. }\end{array}$ & $\begin{array}{l}\text { Consistently demonstrates good } \\
\text { behaviour and attitude conducive to } \\
\text { learning and avoids distractions in } \\
\text { class. }\end{array}$ & $\begin{array}{l}\text { Usually demonstrates a positive } \\
\text { attitude in class and is rarely } \\
\text { distracted. }\end{array}$ & $\begin{array}{l}\text { Generally shows a positive attitude } \\
\text { in class but is sometimes distracted } \\
\text { or inconsiderate of the learning of } \\
\text { others. }\end{array}$ & $\begin{array}{l}\text { Rarely exhibits conduct and attitude } \\
\text { appropriate for a conducive learning } \\
\text { environment. }\end{array}$ \\
\hline & \multicolumn{5}{|c|}{ Self-discipline, Self-reflection, Independent Motivation, Persistence, Conscientious Application to Classwork and Homework } \\
\hline 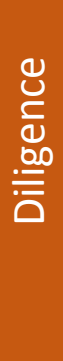 & $\begin{array}{l}\text { Demonstrates an excellent approach } \\
\text { to all activities in class and at home, } \\
\text { presenting work to the best of } \\
\text { his/her ability at all times and } \\
\text { bringing all required equipment to } \\
\text { class. Is independently motivated } \\
\text { and disciplined and takes pride in the } \\
\text { quality of all work produced, } \\
\text { frequently exceeding expectations of } \\
\text { conscientiousness and persistence. }\end{array}$ & $\begin{array}{l}\text { Completes all work to a high } \\
\text { personal standard in a timely manner } \\
\text { and fulfils all expectations for } \\
\text { coursework. Brings all equipment to } \\
\text { class. Demonstrates a self-disciplined } \\
\text { approach to all activities and often } \\
\text { independently persists when } \\
\text { academically challenged. }\end{array}$ & $\begin{array}{l}\text { Usually completes work to a good } \\
\text { personal standard, brings equipment } \\
\text { to class and demonstrates self- } \\
\text { discipline in application to } \\
\text { coursework. }\end{array}$ & $\begin{array}{l}\text { Shows some self-discipline in } \\
\text { completing most coursework with a } \\
\text { reasonable level of application. }\end{array}$ & $\begin{array}{l}\text { Rarely fulfils expectations with } \\
\text { regard to self-discipline, } \\
\text { conscientiousness and application tc } \\
\text { coursework. }\end{array}$ \\
\hline \multicolumn{6}{|c|}{ Classroom Focus, Communication (Verbal and Body Language), Personal Presentation and Punctuality, Participation and Contribution in Groups and Class } \\
\hline 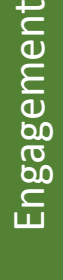 & $\begin{array}{l}\text { Consistently demonstrates the } \\
\text { highest standards of attention and } \\
\text { focus in class, contributing where } \\
\text { appropriate to group or classroom } \\
\text { forums and/or demonstrating active } \\
\text { listening skills at all times. Is always } \\
\text { punctual and well-presented. }\end{array}$ & $\begin{array}{l}\text { Actively listens to all teacher } \\
\text { explanations and instructions and } \\
\text { where appropriate, participates in } \\
\text { group and class forums. Is punctual } \\
\text { and well-presented. }\end{array}$ & $\begin{array}{l}\text { Usually demonstrates good focus in } \\
\text { class, listening to teacher } \\
\text { instructions and explanations and } \\
\text { appropriately participating in group } \\
\text { and class forums. Is usually punctual } \\
\text { and well-presented. }\end{array}$ & $\begin{array}{l}\text { Is generally well-focused and on-task } \\
\text { in class, participating from time to } \\
\text { time in group class forums. }\end{array}$ & $\begin{array}{l}\text { Is rarely focused in class and often } \\
\text { off-task. }\end{array}$ \\
\hline
\end{tabular}

Figure 4a. Refined and simplified effort tracking rubric. 


\section{JOURNAL OF LEARNING ANALYTICS}

(2016). Tracking and visualizing student effort: Evolution of a practical analytics tool for staff and student engagement. Journal of Learning Analytics, 3(2), 165-193. http://dx.doi.org/10.18608/jla.2016.32.8

Effort Tracking Rubric - Pastoral Interpretation

\begin{tabular}{|c|c|c|c|c|c|}
\hline & 5- Outstanding & 4- Very Good & 3-Good & 2-Fair & 1- Unsatisfactory \\
\hline Behaviour & 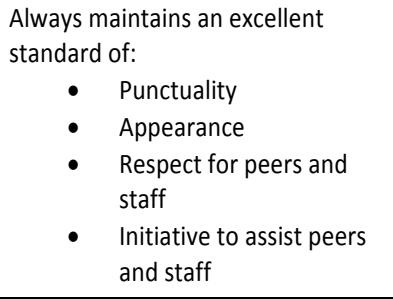 & 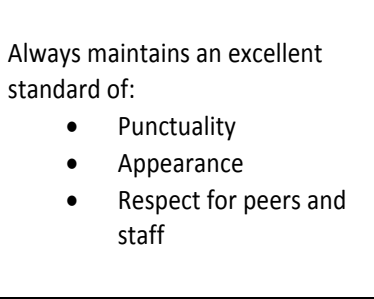 & $\begin{array}{l}\text { Usually maintains a high standard of: } \\
\text { - Punctuality } \\
\text { - } \\
\text { - } \text { Respearance } \\
\text { Rest for peers and staff }\end{array}$ & $\begin{array}{l}\text { Generally maintains an } \\
\text { acceptable standard of: } \\
\text { - Punctuality } \\
\text { - Appearance } \\
\text { - Respect for peers } \\
\text { and staff }\end{array}$ & $\begin{array}{l}\text { Does not maintain an acceptable standard of: } \\
\text { - Punctuality } \\
\text { - } \text { Appearance } \\
\text { - Respect for peers and staff }\end{array}$ \\
\hline Diligence & $\begin{array}{l}\text { Without teacher reminders, always } \\
\text { maintains an excellent standard of: } \\
\text { - Organisation } \\
\text { - Usage of Diary and } \\
\text { - Locker } \\
\text { Planning and Goal- } \\
\text { Setting }\end{array}$ & $\begin{array}{l}\text { Always maintains an excellent } \\
\text { standard of: } \\
\text { - Organisation } \\
\text { - Usage of Diary and } \\
\text { Locker }\end{array}$ & $\begin{array}{l}\text { Usually maintains a high standard of: } \\
\text { - Organisation } \\
\text { - Usage of Diary and Locker }\end{array}$ & $\begin{array}{l}\text { Generally maintains an } \\
\text { acceptable standard of: } \\
\text { - Organisation } \\
\text { - Usage of Diary } \\
\text { and Locker }\end{array}$ & $\begin{array}{c}\text { Does not maintain an acceptable standard of: } \\
\text { - Organisation } \\
\text { - Usage of Diary and Locker }\end{array}$ \\
\hline Engagement & $\begin{array}{l}\text { Always maintains an excellent } \\
\text { standard of: } \\
\text { - Participation in tutor } \\
\text { - } \text { activities } \\
\text { Participation in the } \\
\text { - } \text { wider life of the school } \\
\text { - Academic rigor } \\
\text { - Service }\end{array}$ & $\begin{array}{l}\text { Always maintains an excellent } \\
\text { standard of: } \\
\text { - Participation in tutor } \\
\text { - } \text { activities } \\
\text { Participation in the } \\
\text { - } \text { wider life of the school } \\
\text { Academic rigor }\end{array}$ & $\begin{array}{l}\text { Usually maintains a high standard of: } \\
\text { - Participation in tutor } \\
\text { activities } \\
\text { - Participation in the wider life } \\
\text { of the school } \\
\text { - Academic rigor }\end{array}$ & $\begin{array}{l}\text { Generally maintains an } \\
\text { acceptable standard of: } \\
\text { - Participation in } \\
\text { tutor activities } \\
\text { - Participation in } \\
\text { the wider life of } \\
\text { the school } \\
\text { - Academic rigor }\end{array}$ & $\begin{array}{l}\text { Does not maintain an acceptable standard of: } \\
\text { - Participation in tutor activities } \\
\text { - } \quad \text { Participation in the wider life of the } \\
\text { Academic rigor }\end{array}$ \\
\hline
\end{tabular}

Figure 4b. Pastoral interpretation of effort tracking rubric. 
(2016). Tracking and visualizing student effort: Evolution of a practical analytics tool for staff and student engagement. Journal of Learning Analytics, 3(2), 165-192. http://dx.doi.org/10.18608/jla.2016.32.8

Figure 5: Whole school effort list.

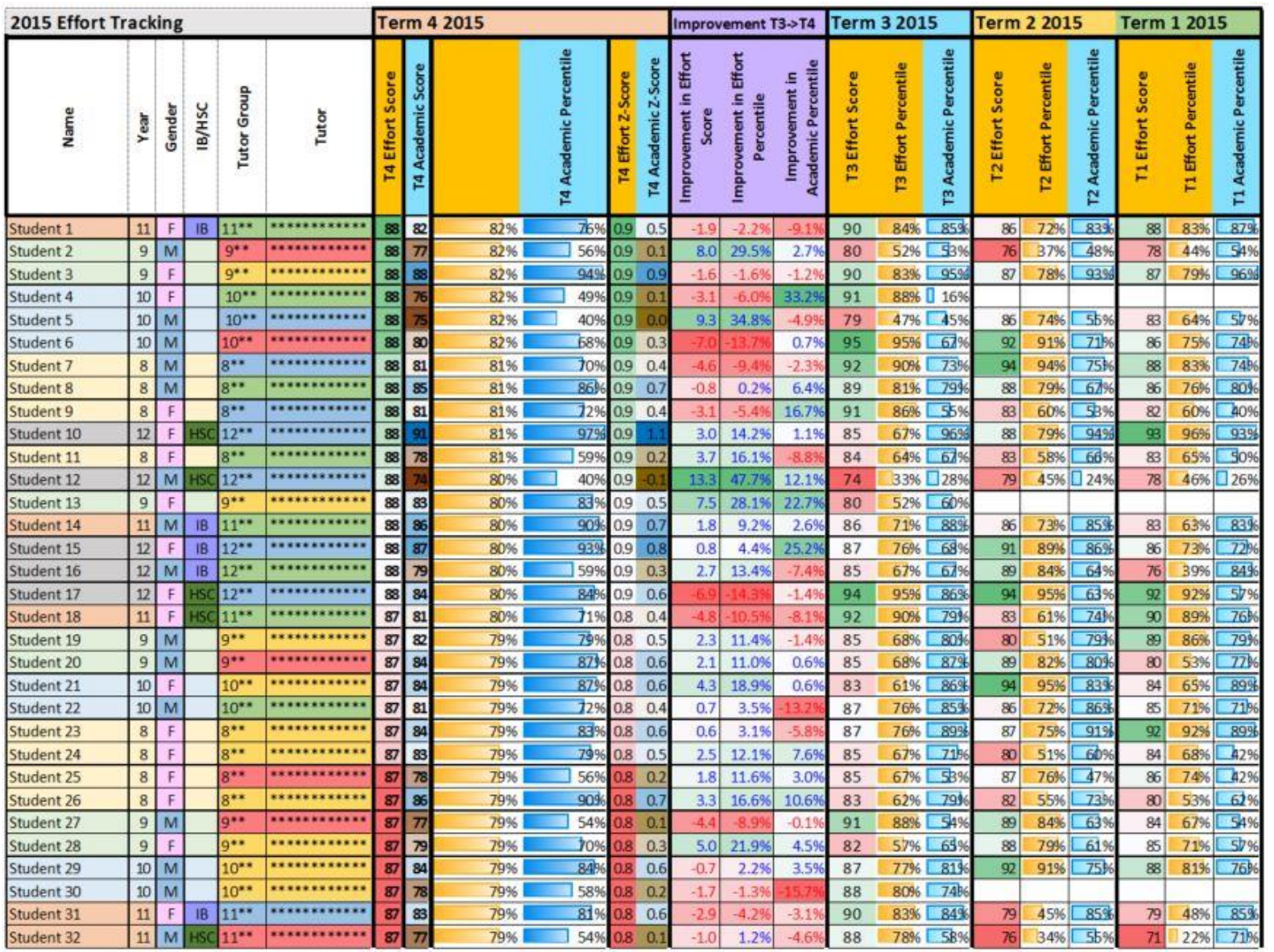

Each term, a whole-school list was produced with columns indicating the effort score from previous terms, school and year-group percentiles, and the improvement made since the previous term (see Figure 5). This list also included academic cohort percentile, based on an aggregated rank over all subjects and latterly an overall "academic score," which is in development as a single number from 40 to 100 and will be described in more detail in Section 3.5. Following teacher feedback and correlation analysis, it was decided to condense the year-group and whole-school effort percentile data to a single percentile in the summary data due to the extremely high positive correlation between the two (0.9966). Clearly, it is important that this correlation coefficient be monitored from term to term to ensure that using a single percentile remains a valid indicator.

The Effort List in Figure 5 was created (by the author) in Microsoft Excel, making use of conditional formatting options to highlight students' significant statistics such as a substantial improvement or decrease in effort score from one term to the next. These highlighted statistics are designed to assist pastoral tutors in selecting pertinent information to help shape the ir one-on-one discussions with students. Typically, red is used for concern and green for positive accomplishment.

A visualization tool developed (by the author) for student intervention and analysis is the use of a three-dimensional motion chart (bubble-chart, implemented in Google Sheets) that shows the progress of student effort-achievement paths on a two-dimensional plane as time elapses. Figures 6a and $6 \mathrm{~b}$ display all secondary school students, with girls in blue and boys in green, at two separate times of the year. The position of a single student is determined by his or her effort on the horizontal 
(2016). Tracking and visualizing student effort: Evolution of a practical analytics tool for staff and student engagement. Journal of Learning Analytics, 3(2), 165-192. http://dx.doi.org/10.18608/jla.2016.32.8

scale and achievement on the vertical scale, and this position can be traced over the course of the year to reveal a unique student track, as can be seen in Figure 7. Being able to select and watch the path of a single student while conducting a one-on-one interview about their effort is an extremely persuasive method of encouraging student motivation and self-reflection. All students have shown great interest in observing and analyzing their track.

Figure 6a: Motion or "bubble" chart displaying all student effort and achievement (Term 1, 2015).

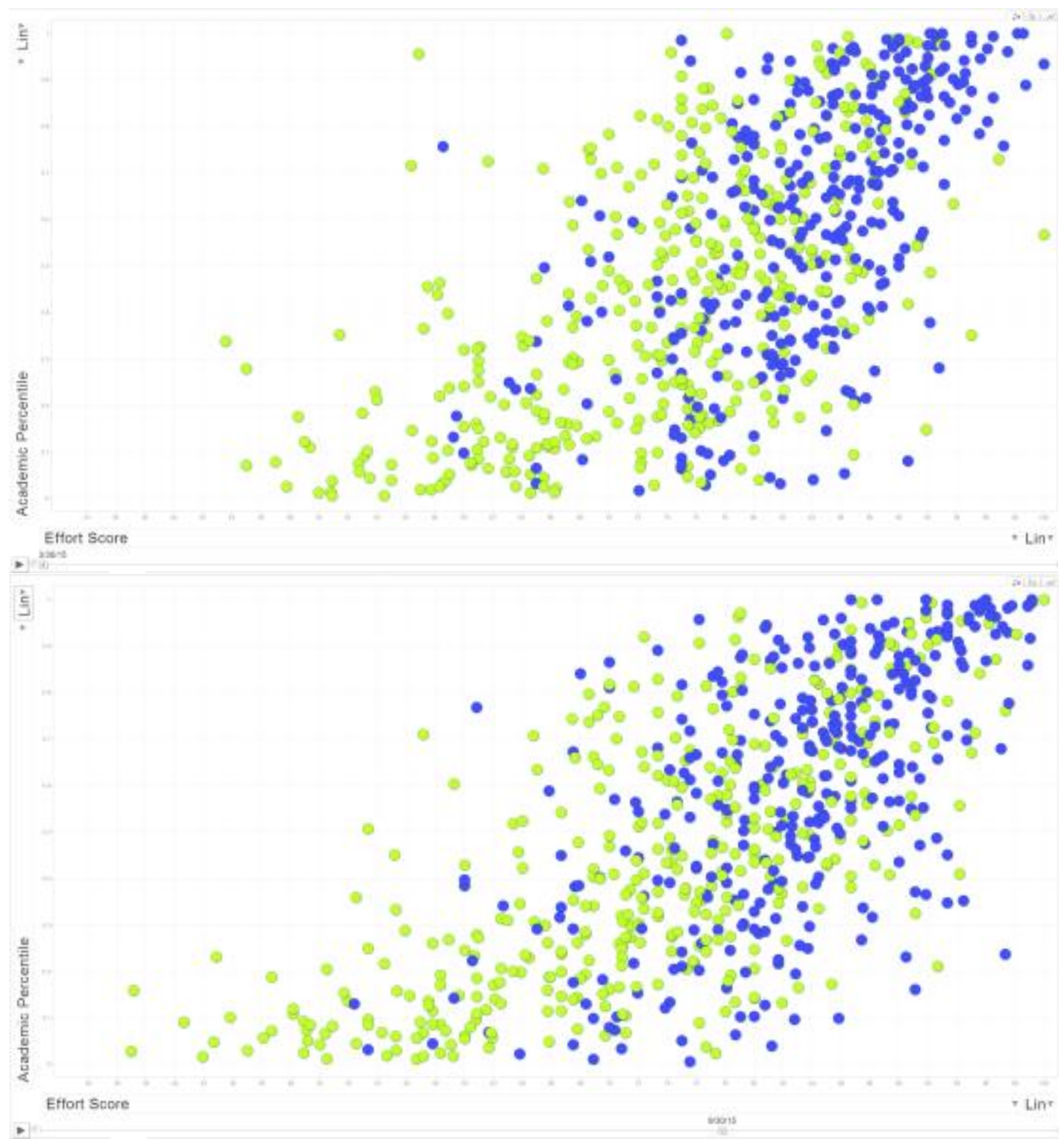

Figure 6b: Motion or "bubble" chart displaying all student effort and achievement later in the year (Term 3, 2015). 


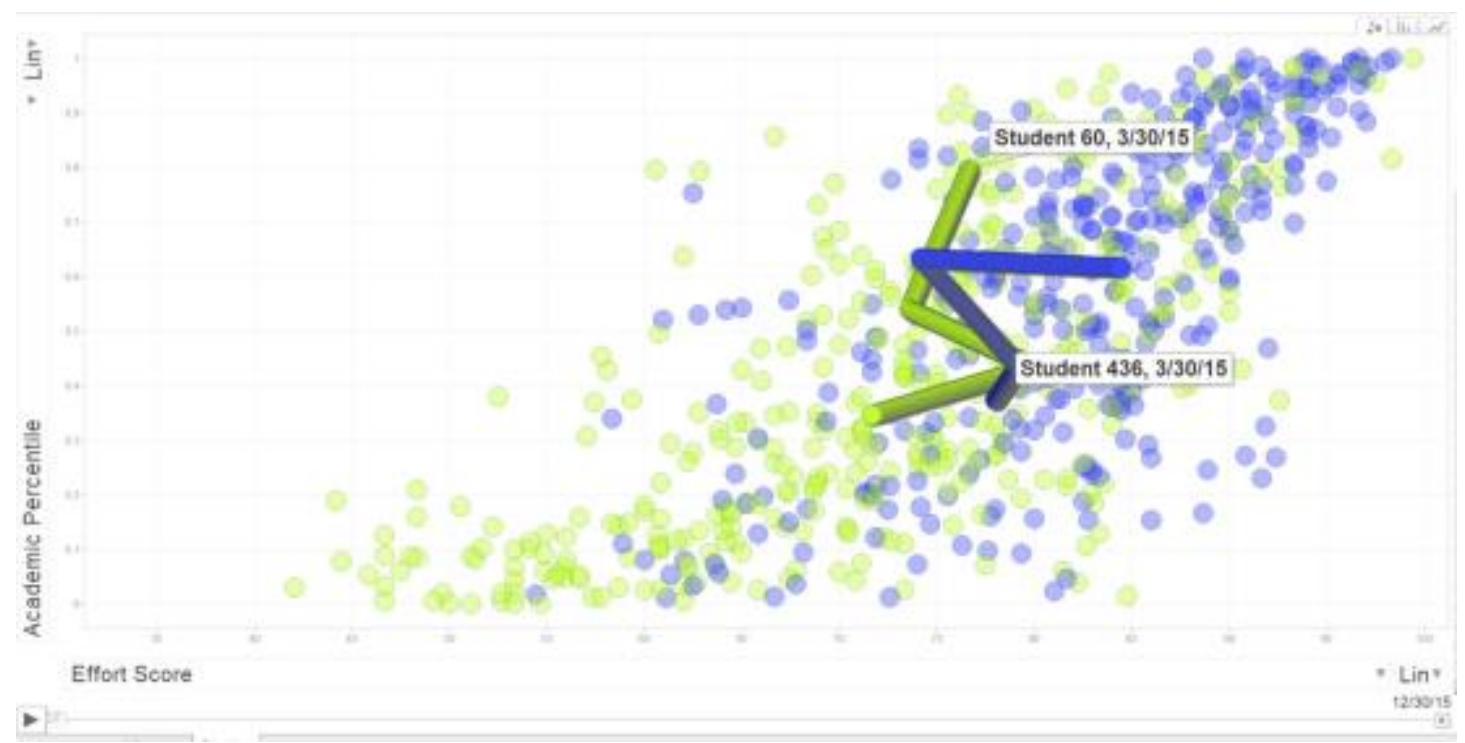

Figure 7: Motion or "bubble" chart displaying two unique student tracks.

To see a demonstration of the motion chart's animation, see: https://vimeo.com/168306314

\subsection{Analytics-Based Interventions}

In addition to every student having a conversation with their pastoral tutor each term where they are made aware of their effort scores, further intervention by year advisors and more senior members of the school management is carried out with those students who 1) appear on the bottom of the effortscore list, 2) have seen a sharp decline in effort, and 3) have a very high ratio of academic to effort scores (indicating students who are achieving at a level much higher than is commensurate with their effort). These interventions typically involve a conversation between the student and teacher that focuses on specific effort criteria and subjects in which the student could improve their behaviour, diligence, or engagement using data such as in Figure 3a. Students are encouraged to set numerical goals that relate to these criteria and to aim for a specific overall effort grade by the end of the term, and parents are usually included at this stage. This is then reinforced as the term progresses using feedback from classroom teachers and further one-on-one conversations with the student.

Setting realistic and measurable targets for effort increases the likelihood of student s achieving their goals and reinforces the school's "success-focus" on effort rather than academic results. Most importantly, students begin to real ize that they can dramatically affect their effort scores by changing their attitude to class and, moreover, that this change is reflected in an immediate improvement in their effort score. Clearly, this is a much swifter reinforcement of a positive work ethic than waiting for a corresponding improvement in achievement, which might follow more gradually in due course. 
(2016). Tracking and visualizing student effort: Evolution of a practical analytics tool for staff and student engagement. Journal of Learning Analytics, 3(2), 165-192. http://dx.doi.org/10.18608/jla.2016.32.8

\subsection{Reflections on the data}

It is very clear that girls' distribution of effort scores is significantly higher than boys', although the differential appears to widen in the middle secondary years and narrow once again in the senior secondary years. This can be seen in the Appendix, in Figures 9a to 9f for Years 7 to 12 respectively (Term 1, 2015), and overall in Figures 6a and 6b (Terms 1 and 3, 2015). However, the disparity in achievement distributions, although also significant, appears much less pronounced. This can be seen graphically in Figures $6 a$ and $6 \mathrm{~b}$ by looking at the vertical distributions of the two colours rather than the horizontal distribution.

Mathematically this is borne out by the relative positions of the academic mean in all year-groups, as can be seen in Table 2 (Term 4, 2015), with boys still below girls academically, but by a far less pronounced margin than with effort. The standard deviation is al so wider for boys in all years for effort and, in all but Year 9, for academic achievement, although the difference in the spread of effort distributions between boys and girls is more pronounced than the difference in the spread of achievement data.

These results suggest that perhaps teachers are grading boys' effort more harshly than girls', or perhaps the type of engagement seen by girls is superficially more focused but does not necessarily translate into academic results. Another more controversial interpretation would be that boys do not need to try as hard as girls do, but it seems unlikely that this is the case. Further analysis is required and this will feed back into a dialogue with teachers' interpretations of the effort rubric and what "effort" looks like in class.

Table 2: Summary statistics for academic effort and achievement data (Term 4, 2015).

\begin{tabular}{|l|c|c|c|c|}
\hline & Effort Mean & Effort SD & Academic Mean & Academic SD \\
\hline Year 7 & 77.3 & 11.6 & 74.5 & 10.6 \\
\hline Y7 Boys & 72.0 & 11.7 & 71.5 & 11.2 \\
\hline Y7 Girls & 82.6 & 8.8 & 77.4 & 9.1 \\
\hline Year 8 & 77.8 & 11.4 & 74.8 & 9.3 \\
\hline Y8 Boys & 72.4 & 12.0 & 71.8 & 9.2 \\
\hline Y8 Girls & 83.6 & 7.1 & 78.1 & 8.2 \\
\hline Year 9 & 78.0 & 10.4 & 74.7 & 10.3 \\
\hline Y9 Boys & 74.4 & 10.8 & 72.0 & 9.5 \\
\hline Y9 Girls & 81.6 & 8.6 & 77.5 & 10.4 \\
\hline Year 10 & 78.0 & 12.8 & 75.2 & 9.4 \\
\hline Y10 Boys & 72.3 & 13.2 & 72.7 & 9.7 \\
\hline Y10 Girls & 84.1 & 9.1 & 78.0 & 8.2 \\
\hline Year 11 & 76.9 & 11.8 & 75.3 & 9.1 \\
\hline Y11 Boys & 72.9 & 11.8 & 72.3 & 8.7 \\
\hline Y11 Girls & 82.2 & 9.4 & 79.2 & 8.1 \\
\hline Overall & 77.6 & 11.7 & 74.9 & 9.8 \\
\cline { 2 - 5 } Boys & 72.8 & 12.0 & 72.0 & 9.7 \\
\cline { 2 - 5 } & 82.8 & 8.6 & 78.0 & 8.9 \\
\hline
\end{tabular}


(2016). Tracking and visualizing student effort: Evolution of a practical analytics tool for staff and student engagement. Journal of Learning Analytics, 3(2), 165-192. http://dx.doi.org/10.18608/jla.2016.32.8

\subsection{Towards an Aggregate Achievement Score}

In order to provide a consistent, dependent variable on which to base effort-achievement analysis, it is necessary to develop an academic achievement score that is invariant to fluctuations in the level of difficulty of individual assessment tasks. To this aim, the author has developed a weighted and normalized "achievement score" based entirely on standard deviation. Broadly, a student's achievement in every assessment is measured by his or her z-score (number of standard deviations from the cohort mean) and multiplied by the individual assessment weighting. The sum of all these weighted deviations from the mean is calculated for each student and then normal ized by dividing by the total weighting of all the student's assessments. The resulting figure is a weighted standardized and normalized measure of the student's deviation from the mean, which can then be translated into a score by multiplying by a "spread-variable" and adding an "average-offset" adjustment. This method gives an academic score comparable between students of different cohorts provided that the ability range of each cohort is broadly similar and assuming a normal distribution of scores. By manipulating the two "spread-variable" and "average-offset" variables, it can be ensured that this "academic score" ranges from about 40 to 100 in order to be in line with effort score and other common indicators such as the ATAR. ${ }^{3}$ This "academic score" is still in its infancy but already appears to be a reliable relative indicator of academic achievement.

\subsection{Staff Reactions}

It has been described how staffhave been engaged in consultation around successive iterations of the tool. In this section, the author reflects on some of the ongoing challenges that this approach presents.

In the initial staff consultation, different criteria were discussed to ensure the best overall description of student effort without undue overlap between criteria. Many staff suggested criteria such as "Independence," “Organization," and "Risk Taking," but these were not adopted due to the difficulty in accurately reporting on every student in these aspects of their character. Moreover, there were vibrant debates between staff on the semantics of criteria descriptors: would "focus" be a better descriptor than "engagement"? Perhaps "respect" would be better than "behaviour"? In the end, there were many possible combinations of criteria that could have provided similar overall coverage and discrimination of student effort, but a decision had to be made to adopt a particular collection of criteria. This was made with due reference to the comments of all staff in the consultation process, which also improved staff "buy-in" of the resulting refinement of the tool.

One member of staff expressed concern about being able to reflect the rubric from term to term accurately and asked whether it was possible to pre-fill the teacher input screens with the previous term's grades for each student so as to be able to better ensure consistency of reporting by teachers from term to term. Clearly, there appears to be some merit in this idea at first, but on further reflection, it was dismissed due to the overwhelming likelihood that it would encourage teachers to

\footnotetext{
3 The Australian Tertiary Admission Rank (ATAR) is a number from 0 to 99.95 representing an academic ranking; it is a dministrated by the Australian University Admissions Centre (UAC) and "provides a measure of a student's overall academic a chi evement in relation to that of other students and helps universities ra nk a pplicants for selection into their courses." See http://www.uac.edu.au/atar/ for more details.
} 
(2016). Tracking and visualizing student effort: Evolution of a practical analytics tool for staff and student engagement. Journal of Learning Analytics, 3(2), 165-192. http://dx.doi.org/10.18608/jla.2016.32.8

develop a "fixed mindset" with respect to their students both in terms of the relative ease of not changing grades as well as an inherent inertia towards radically re-assigning them. It was felt that any teacher who wished to be diligent in maintaining consistency of their distribution of grades could keep copies of previous terms' grades and use these to inform their current reporting.

Although many staff supported and liked reporting on a single effort criterion at a time, one member preferred to be able to see all effort criteria awarded in a single screen to ensure consistency. This was dismissed for the same reasons as the previousconcern, believing that this would lead to a much higher correlation between criteria; this was borne out by the correlation analysis mentioned earlier in this article.

\subsection{Software Implementation Practicalities}

The practicalities of implementing the effort tracking system to capture data each term, via the desired single-criterion screens for a whole class, proved challenging, and are worth reporting since these are the sorts of obstacles that will beset almost any analytics project that must co-exist with legacy systems.

Initial conversations with the school's database supplier proved fruitless, partly due to the semesterized nature of the current system, and it was decided to run the entire effort-tracking pilot outside this system using a Google Sheets Script developed specifically for this purpose. Although the implementation of the "Effort Input Script" was successful and demonstrated proof of concept, it developed through three distinct versions with several staff requests implemented, such as the option to print after submission of grades.

Due to the data being hosted in the cloud and the need for staff to access the entire Google Sheet simultaneously, there were initially problems with some of the input data not being properly transferred to the master sheet. This was due to the initial design of the user interface, written in JavaScript, which referenced a local copy of the data to improve input speed and performance. In the first version of the "Effort Grading Script," some of the data from the local copy did not correctly transfer to the remote master sheet due to Internet dropout, inconsistent access to the Google sheet, and other individual user issues. Further refinement in the script then resulted in unacceptable delays due to all data being checked for accuracy every time there was a single change in input. Final ly, a compromise was reached with the master sheet being checked with the local copy only after each input screen. Although there were still occasional lapses in the transfer of data, the resulting version 3 script allowed for swiftdata entry and an accep table compromise in accuracy in terms of the amount of follow-up with teachers for missing grades. Nevertheless, it is seen as essential that this reporting eventually becomes absorbed within the current structure of the school's database system, particularly if the effort grading becomes part of the school's official reporting to parents.

In investigating what reports to parents may be possible for a single student, box-and-whisker diagrams were produced for each of a student's subjects, displaying the range of effort grades awarded for each criteria as well as an overall distribution for the class (displayed on a 1 (Unsatisfactory) to 5 (Outstanding) scale for comparison with individual criteria). The student's performance was highlighted on each box-and-whisker diagram with a black diamond, as can be seen 
(2016). Tracking and visualizing student effort: Evolution of a practical analytics tool for staff and student engagement. Journal of Learning Analytics, 3(2), 165-192. http://dx.doi.org/10.18608/jla.2016.32.8

in Figure 8a. Note that in each of these specific diagrams the range of values is from 2 (Fair) to 5 (Outstanding).

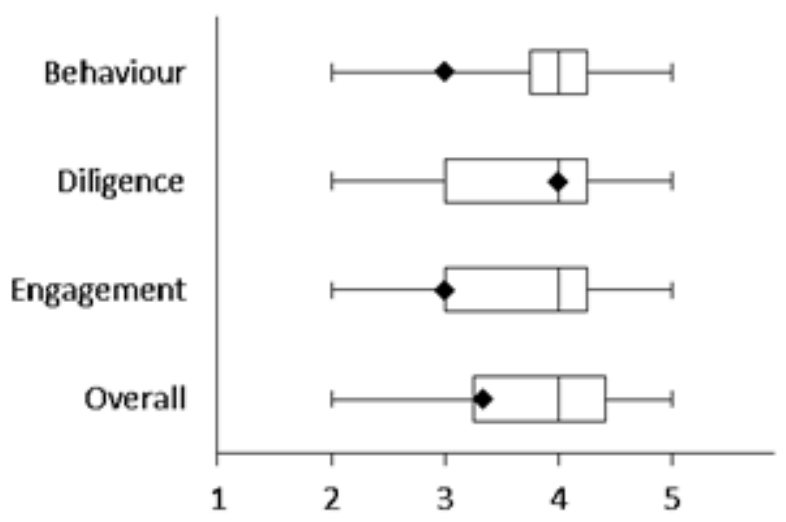

Figure 8a: Possible subject-specific Effort Report using box-and-whisker diagrams.

However, this proposed reporting highlighted teachers who were more egal itarian in their reporting of effort or who perhaps displayed less knowledge of their students' individual characteristics. This might be indicative of subjects in which teachers saw particular classes only occasionally, especially if reporting at the end of Term 1. For an extreme example, see Fig ure 8b: Data has been manipulated to assign all students the same grade for each criteria.

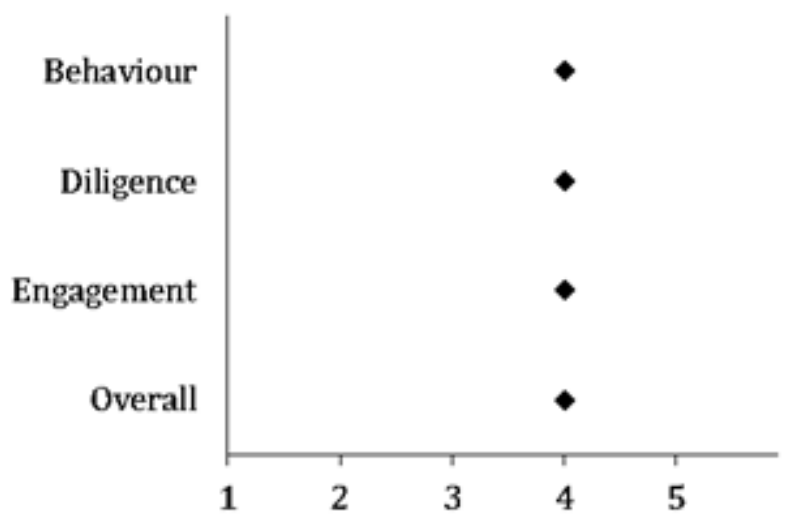

Figure 8b: Manipulated subject-specific Effort Report with all students awarded the same grade (4 - Very Good).

Clearly, it would be undesirable to send a report to parents such as the one in Figure $8 \mathrm{~b}$ and it is necessary to ensure that this does not happen. This might be addressed through staff awareness (by alerting staff that their distribution of grades will become visible to parents if this sort of reporting is implemented). Furthermore, it may be appropriate for certain subjects to grade effort on a lessfrequent basis due to the relative frequency of their classes. In the effort pilot, it was decided to adopt this approach with one subject in which all secondary students in years 7 to 10 were taught by a team of two teachers once per week. In consultation with this department, it was decided that effort grading would take place for a single year-group each term, with year 10 in term 1, year 9 in term 2, and years 8 and 7 in terms 3 and 4 respectively. This would ensure that teachers knew their students well at the time of reporting (the older students would have been taught in previous years) and that there were reasonable reporting overheads each term. This "stratified" reporting also ensured that 
(2016). Tracking and visualizing student effort: Evolution of a practical analytics tool for staff and student engagement. Journal of Learning Analytics, 3(2), 165-192. http://dx.doi.org/10.18608/jla.2016.32.8

while this subject played a role in a student's effort grade over the course of a year, it onlycontributed $25 \%$ compared to other subjects that occurred more frequently and were therefore more significant.

The issue of how relativelysignificant each subject should be in the creation of an overall effort score is ongoing. With the exception of the example above, all subjects currently count equally towards a student's effort score; however, there may be subjects where a student has more than one teacher or where a senior student has extension units with the same teacher. All these factors throw up further decisions and refinements into obtaining a single score for student effort, one comparable across all cohorts and year-groups. Furthermore, this relative weighting of subjects is perhaps even more contentious in the creation of an academic score. Should certain subjects such as Mathematics and English be weighted above other subjects? Certainly, this appears to be the case in the creation of a student's ATAR by the University Admissions Centre (UAC). What about the relative academic weighting in situations where students study different levels of the same subject, such as in senior years where at least three levels of Mathematics are offered? Indeed, if we are to use the (year 12) ATAR as a model on which to base a single academic score for students of all years, it then places an onerous responsibility to reflect the correct weighting of subjects all the way down to year 7 . However, will this result in undesirable consequences such as early tactical subject selection? If the ATAR is not used as a model for creating the academic score, there may be a discrepancy between what students have been expecting from the school-assigned academic score and subsequent rank, and what they receive at the end of their schooling from UAC. Clearly, many questions remain in addressing and refining the method before arriving at what will surely be a compromise between accuracy and necessity. Nevertheless, much of the purpose and strength of student tracking is in the progression and monitoring of student progress together with the conversations it generates between students, teachers, and parents, rather than on the raw data itself.

Importantly, the results of the effort-tracking pilot have also raised staff awareness regarding the behaviours teachers seek in students. Are teachers' expectations of students encouraging quiet and co-operative behaviour? Does such behaviour manifest the best learning outcomes? Are sociologically instilled teacher expectations of student behaviour biased towards "feminine" characteristics at the expense of nurturing male patterns of engagement and learning? The results of this study appear to lend support to some of these suggestions. There certainly appears to be plenty of scope for further research.

\subsection{Student Reactions}

In our experience to date, sharing this effort/achievement tracking data in the context of a student mentoring conversation generates tremendous interest, especially when the data is broken down to reveal the make-up of effort scores for each term. Students are fascinated to learn of the whole-school distribution of effort and achievement, and how they fit into that picture, highlighted so clearly in their motion track.

Part of the motivational effect of reviewing data from a previous term or year with a student is that there is a natural disconnect between the timing of the conversation and the "snapshot" of the student, which took place in the past. For teenagers, there is an inherent assumption that they will be older, wiser, and more mature after even a few weeks. 
(2016). Tracking and visualizing student effort: Evolution of a practical analytics tool for staff and student engagement. Journal of Learning Analytics, 3(2), 165-192. http://dx.doi.org/10.18608/jla.2016.32.8

At the beginning of a new term, a student is typically fresher and more willing to evaluate prior performance and effort critically with a view to believing themselves capable of improving their behaviour, diligence, and engagement in the term ahead. It is important that all such conversations be positively framed with a view to building self-motivation and helping to scaffold a plan for the term ahead with specific numerical goalsfor a student's effort, broken down by subject and/or criteria. Just as with the dispositional analytics approach of Buckingham Shum and Deakin Crick (2012), it is also imperative that the student "owns" the effort grades from a previous term. To this end, having shared the breakdown of effort score, it is vital to ask the question, "Do you feel that this is an accurate reflection of your efforts as they were at the end of last term?" Most students broadly agree with their teachers' effort grading, sometimes believing that their teachers have been a bit generous in some subjects. In fact, by emphasizing the tracking aspect of the data, it is usually motivating for a low-effort student to know that he or she can easily improve their score in the upcoming term.

In the role of Dean of Students, the author has recently conducted several one-on-one conversations with students at the lower end of the school's effort scores in years 9 to 12 . The student is told that the purpose of the meeting is not a punitive one, but rather a way of supporting and helping them to improve their poor effort score from the previous term. Conversations usually start by looking at the student's effort scores over the past year and the breakdown of the previous term'seffort score using the data in Figure $3 a$.

In the one-on-one meeting, both parties analyze whether there are specific subjects of concern and/or specific criteria in which the student could improve. Conversations may then turn to discussing what "engagement" looks like from a teacher's perspective or strategies for ensuring behaviour is maintained in class, such as sitting away from "trouble" and not shouting out. If diligence is the main problem, discussions centre on organizational skills sand producing a home timetable to try to improve self-discipline. At this point, students generally wish to see their "motion track" against the backdrop of the rest of the school and their data point is selected in the motion chart and the sequence played of the previous year's data with their track highlighted (as in Figure 7). It is explained that the horizontal scale is the effort and the scale on which they can make an immediate impact. It is often useful to discuss why the achievement rise and fall appears to lag behind the effort.

The final stage of the conversation is for the student to come up with some specific targets for the term ahead. This can be in specific criteria and/or specific subjects and it is important to have an overall goal that should be achievable, but also a significant improvement. It is useful in setting this overall effort goal for students to see themselves graphically against the backdrop of all other students. One student said at this point, "Can I actually achieve 75?" The author's response was, "Absolutely. This is effort we are talking about, not academic achievement. You can achieve any score in effort provided you are showing your teachers that you mean business, by behaving in class, completing all work on time, and demonstrating engagement skills such as 'active listening,' participation, and seeking help. Clearly let's not set too high a target initially, as it is not that easy to change your habits and maintain them for a whole term, but by all means select something that you feel you can achieve this term." The student often finds it easier to set this target by looking at their own historical data track set against that of other students (Figure 7), which emphasizes the usefulness of this particularvisualization tool. 
(2016). Tracking and visualizing student effort: Evolution of a practical analytics tool for staff and student engagement. Journal of Learning Analytics, 3(2), 165-192. http://dx.doi.org/10.18608/jla.2016.32.8

Following the meeting, the student's teachers and parents are inform ed about what was discussed and what targets the student set. Teachers are encouraged to explicitly recogn ize any change theysee in the student's attitude and effort and asked for further feedback a few weeks later before holding a subsequent meeting with the student. Helping the student break the term down into smaller periods allows for short-term success and for teachers to change their mindset about the student. More importantly, students feel empowered to influence their own progress. At this point, the author sometimes quotes Stephen Covey: "Sow a thought, reap an action; sow an action, reap a habit; sow a habit, reap a character; sow a character, reap a destiny" (1989, p. 46).

\subsection{Reflections on the "Hawthorne Effect"}

The staff and student feedback is encouraging for the effectiveness of utilizing effort-tracking data to motivate and re-focus students. However, to what extent this is due to the inherent methodology and emphasis on effort instead of academic achievement is open to question, as there is no doubt a large "Hawthorne effect." The "Hawthorne effect" is well known to psychologists and describes the way in which the novelty of being research subjects changes the behaviour of the subjects of that research. It is quite possible that the methodology described here capital izes greatly on the "Hawthorne effect" producing positive results for students who might otherwise find it difficult to re -engage with their studies. However, under the constraints of this work to date, it has not been possible to run what might be regarded in a more controlled experimental paradigm as a control group.

\subsection{Student Self-Assessment of Effort}

In the latest implementation of this tool, students were asked to grade their own effort using thesame interface as teachers, based on the same three criteria as before. There were no clear rubrics provided, but instead, the following descriptions:

- Behaviour: This is your classroom conduct and attitude, politeness and respect, and consideration for the learning of others.

- Diligence: This is how conscientious you are in class and at home. Do you always complete all work? Do you work beyond this? Do you always complete your work to the best of your ability?

- Engagement:This is your classroom focus and communication (verbal and body language), active listening skills, punctuality, participation, and contribution to class.

Following this process, individual student grades were sent to each student, together with their teachers' grades for comparison. They were also given a randomized number and the link to an anonymized bubble-chart of the type shown in Figure 7, where they could see their effort and achievement "motion-track" set against the backdrop of the whole school. Follow-up discussions took place between students and pastoral carers and between students and subject teachers.

Students were surveyed shortly after this process to canvas their views on the effort grading and tracking process and nearly 200 students responded (over a quarter of those invited). The student survey results demonstrated a clear overall endorsement of the effort tracking process with $90 \%$ of students expressing a desire to continue the self-assessment grading on a termly basis together with teacher grading. Over $70 \%$ of students found the comparison of self-grading with teacher grading useful orvery useful and nearly $80 \%$ reported that they were motivated to improve their effort score 
(2016). Tracking and visualizing student effort: Evolution of a practical analytics tool for staff and student engagement. Journal of Learning Analytics, 3(2), 165-192. http://dx.doi.org/10.18608/jla.2016.32.8

the following term. Students were encouraged to state any strategies they were planning to use in order to improve their effort score and many of these responses were specific and targeted at improvement in learning processes, demonstrating reflection of habits of mind, and skills associated with lifelong learning.

In this first trial, $94 \%$ of all students attempted to grade themselves with $3 \%$ of these not completing all criteria. One of the main reasons was technical accessibility issues with Google Docs rather than apathy, and it is hoped that future self-grading will include all students. Once all effort grading had been completed, the results of both the self-assessment and teachers' grades were shared with students and teachers and the discrepancies between the student and teacher grading were highlighted and analyzed. Overall, on average, students and their teachers graded almost identically, although there were wide fluctuations for individual students. Boys' grading showed an average discrepancy with their teachers of -0.1, 0.0, and 0.0 for Behaviour, Diligence, and Engagement respectively (on the 5-point scale described in Section 3.1) whilst girls were a little more critical of their own efforts, having average discrepancies of $-0.4,-0.2$, and -0.3 respectively, as can be seen in Table 3. This degree of overlap is one form of validation of the teacher observation metho dology and tool, namely that staff assessments have validity in students' eyes. Moreover, student-teacher discrepancies draw attention to potential conversations. Students with very low (or indeed, inflated) self-esteem become more visible, and interventions can be considered.

Table 3: Discrepancy between student self-grading and teacher grading (Term 1, 2016)

\begin{tabular}{|l|r|r|r|}
\hline & Behaviour & Diligence & Engagement \\
\hline Whole School Average & -0.2 & -0.1 & -0.1 \\
\hline Whole School Standard Deviation & 1.0 & 1.0 & 1.1 \\
\hline Whole School \% Identical & $62 \%$ & $62 \%$ & $58 \%$ \\
\hline Whole School \% off by more than 1 grade & $13 \%$ & $13 \%$ & $15 \%$ \\
\hline Girls Average & -0.4 & -0.2 & -0.3 \\
\hline Girls Standard Deviation & 1.0 & 1.0 & 1.0 \\
\hline Girls\% Identical & $64 \%$ & $64 \%$ & $60 \%$ \\
\hline Girls\% off by more than 1 grade & $12 \%$ & $12 \%$ & $15 \%$ \\
\hline Boys Average & -0.1 & 0.0 & 0.0 \\
\hline Boys Standard Deviation & 1.1 & 1.1 & 1.1 \\
\hline Boys\% identical & $61 \%$ & $61 \%$ & $57 \%$ \\
\hline Boys\% off by more than 1 grade & $14 \%$ & $14 \%$ & $15 \%$ \\
\hline
\end{tabular}


(2016). Tracking and visualizing student effort: Evolution of a practical analytics tool for staff and student engagement. Journal of Learning Analytics, 3(2), 165-192. http://dx.doi.org/10.18608/jla.2016.32.8

\section{CONCLUSIONS AND FUTURE DIRECTIONS}

Based on educational research into the centrality of making learning dispositions visible to students, this practitioner report has described the iterative development of a practical approach to effort tracking, suitable for use by busy high school teachers. This has been developed to track and feed back to both educators and students how student effort appears to be changing over terms and semesters, in order to scaffold more effective student-tutor conversations. A visual analytics technique using animated bubble charts has proven an engaging way to present such data, as evidenced by student survey results, with students making comments such as:

I really appreciate the effort tracking "bubble chart." I thought it was really interesting seeing my improvement only over the last term; it would be amazing see over the whole school year!

The engagement and professional development of teachers is central to ensuring that such initiatives are sustainable and trusted by staff. Moreover, the strength of this tool lies in the formative aspect of effort assessment, implicit in the student tracking model and regularly reinforced by informed, high quality student-teacher conversations following each successive effort grading period (typically termly).

The use of student tracking data to influence student motivation and achievement appears to be an exciting outcome of this project, as is the potential use of the achievement score data to justify valueadded benefit and extrapolation of current results to final ATARs. However, there is al ways a danger that effort tracking could be used counter-productively as just another summative assessment of student performance, merely increasing the pressure on students rather than seeking to develop intrinsic motivation in them. It is for this reason that schools need to be circumspect about using this data in an ethical manner to redirect the "success-focus" away from high-stakes testing in order to provide a positive impact on student motivation and lifelong learning skills.

Perhaps the most exciting aspect of this implementation of data analysis is the direct positive effect on student motivation and encouraging a "growth mindset" as part of the school "success-focus." It appears that it may provide a means of lessening the impact of high-stakes summative assessment on student motivation, which has negative impacts on intrinsic motivation for learning (Harlen \& Deakin Crick, 2003). In an educational era of ever-burgeoning assessment, with systemic emphasis on performance goals, Harlenand Deakin Crick's review (of the impact of testing on students' motivation for learning) identified the need for increased em phasis on learning goals and for providing feedback to students in relation to these goals. In particular, Duckworth, Fielding, and Shaughnessy (1986) and Roderick and Engel (2001) stressed the importance of using assessment to convey a sense of leaming progress to students and helping to show low-achieving students how to direct their efforts in order to support their self-efficacy. The effort-tracking model developed here, provides schools with a structured means of achieving this aim, and promises to support students' development of qualities associated with effective lifelong learning by acting alongside, but as a moderating influence on statutory high-stakes summative assessment regimes.

At present, our confidence in the approach is based on what staff and students are feeding back from their experiences of the project. This evidence indicates that the initial one-year pilot effort-tracking project at Redlands School has been very successful, both in terms of the interest generated from 
(2016). Tracking and visualizing student effort: Evolution of a practical analytics tool for staff and student engagement. Journal of Learning Analytics, 3(2), 165-192. http://dx.doi.org/10.18608/jla.2016.32.8

students, teachers, and parents as well as the relatively quick and easy reporting methodology by teachers. Harlen and Deakin Crick (2002) ide ntify a key question in their review: "What actions in what circumstances would increase the positive, and decrease the negative impact on students of summative testing and assessment?" It is imperative that any implementation of this tool seeks to do just that, in working alongside the school's academic assessment program. As Harlen and Deakin Crick state, "For continued learning, the motive needs to be intrinsic, the reward being in the process of learning and in the recognition of being in control of, and responsible, for one's own learning" (2002, p. 2).

So far, the effort-tracking tool has produced interesting data and findings that deserve further investigation and research, and has more scope for refinement and development over the coming years. Future work should establish a more formal evidence base, but to date has been beyond the scope of this practitioner-initiated program. Otherfuture possibilities include more detailed analysis of "motion tracks" on the "bubble" chart in Figure 7, including categorizing typical tracks and assessing whether they correlate to particular types of students. Other avenues might introduce additional tools for self-report dispositional analytics, such as CLARA (Deakin Crick et al., 2015; CLARA, 2016), which could provide additional insights into student resilience and agency, and further enrich student-tutor interviews.

\section{REFERENCES}

Black, P., \& Wiliam, D. (1998). Assessment and classroom learning. Assessment in Education, 5(1), 774. http://dx.doi.org/10.1080/0969595980050102

Bryk, A. (2015). Learning to improve: How America's schools can get better at getting better. Boston: Harvard Education Press.

Buckingham Shum, S., \& Deakin Crick, R. (2012). Learning dispositions and transferable competencies: Pedagogy, modelling and learning analytics. Proceedings of the 2 nd International Conference on Learning Analytics and Knowledge (LAK '12), 92-101. http://dx.doi.org/10.1145/2330601.2330629

Costa, A. L., \& Kallick, B. (2009). Habits of mind across the curriculum: Practical and creative strategies forteachers. Alexandria, VA: Association for Supervision and Curriculum Development.

Covey, S. R. (1989). The 7 Habits of Highly Effective People: Powerful Lessons in PersonalChange. New York: Free Press.

CLARA (2016). Crick Learning for Resil ient Agency: Learning Emergence LLC. [Web site]. Retrieved from http://clara.learningemergence.com

Deakin Crick, R., Huang, S., Ahmed-Shafi, A., \& Goldspink, C. (2015). Developing resilient agency in learning: The internal structure of learning power. British Journal of Educational Studies, 63(2), 121-160. http://dx.doi.org/10.1080/00071005.2015.1006574

Duckworth, K., Fielding, G., \& Shaughnessy, J. (1986). The relationship of high school teachers' class testing practices to pupils' feelings of efficacy and efforts to study. Portland, OR: University of Oregon.

Dweck, C. S. (2006). Mindset: The new psychology of success. New York: Random House.

Jackson, R. C. (2014). Concentration. In R.C. Eklund, G. Tennenbaum (Eds.), Encyclopedia of sport and exercise psychology (Vol.1), (pp. 159-161). Thousand Oaks, CA: Sage Publications. 
(2016). Tracking and visualizing student effort: Evolution of a practical analytics tool for staff and student engagement . Journal of Learning Analytics, 3(2), 165-192. http://dx.doi.org/10.18608/jla.2016.32.8

Harlen, W., \& Deakin Crick, R. (2002). A systematic review of the impact of summative assessment and tests on students' motivation for learning. In: Research Evidence in Education Library. London: EPPI-Centre, Social Science Research Unit, Institute of Education.

Harlen, W., \& Deakin Crick, R. (2003). Testing and motivation for learning. Assessment in Education, 10(2), 169-207. http://dx.di.org/10.1080/0969594032000121270

Hobsons. (2014). Student Feedback and Progressive Reporting (Report). Melbourne: Hobsons Australia Pty Ltd. Retrieved from http://www.bps.sa.edu.au/ files/f/16997/Hobsons student feedback and progressive reporting June14.pdf

Kellaghan, T., Madaus, G., \& Raczek, A. (1996). The use of external examinations to improve student motivation. Washington, DC: AERA.

Martin, A. J. (2010). Building classroom success: Eliminating academic fear and failure. London: Continuum.

McDonald, A. (2001). The prevalence and effects of test anxiety in school children. Educational Psychology, 21, 89-101. http://dx.doi.org/10.1080/01443410020019867

Perkins-Gough, D. (2013, September). Educational leadership: The significance of grit - A conversation with Angela Lee Duckworth. Educational Leadership, 71(1), pp. 14-20. Retrieved from http://www.ascd.org/publications/educational-leadership/sept13/vol71/num01/TheSignificance-of-Grit@-A-Conversation-with-Angela-Lee-Duckworth.aspx

Pollard, A., Triggs, P., Broadfoot, P., McNess, E., \& Osborn, M. (2000). What pupils say: Changing policy and practice in primary education. London: Continuum.

Roderick, M., \& Engel, M. (2001). The grasshopper and the ant: Motivational responses of low achieving pupils to high stakes testing. Educational Evaluation and Policy Analysis, 23, 197228.

Schunk, D. (1991). Self-efficacy and academic motivation. Educational Psychologist, 26, 207-231. http://dx.doi.org/10.1080/00461520.1991.9653133

Smith, L. H., \& Kays, T. M. (2010). Sports psychologyfordummies "cheat sheet." Mississauga, ON: John Wiley \& Sons Canada. 
(2016). Tracking and visualizing student effort: Evolution of a practical analytics tool for staff and student engagement. Journal of Learning Analytics, 3(2), 165-192. http://dx.doi.org/10.18608/jla.2016.32.8

\section{APPENDIX: DISTRIBUTION OF EFFORT GRADES BASED ON GENDER AND YEAR-GROUP (TERM 1, 2015).}

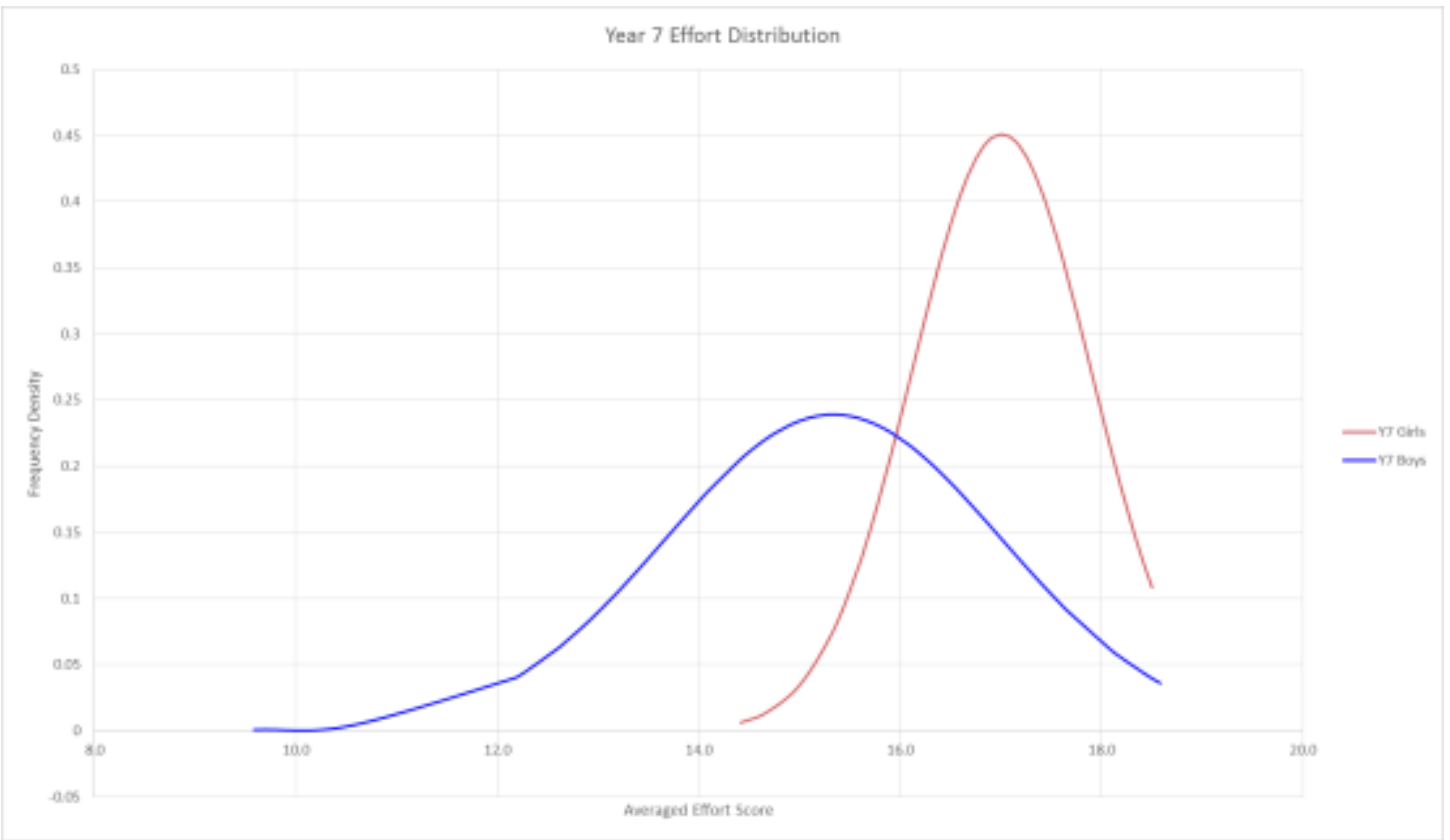

Figure 9a: Distribution of Year 7 Boys' and Girls' Effort Grades (Term 1, 2015).

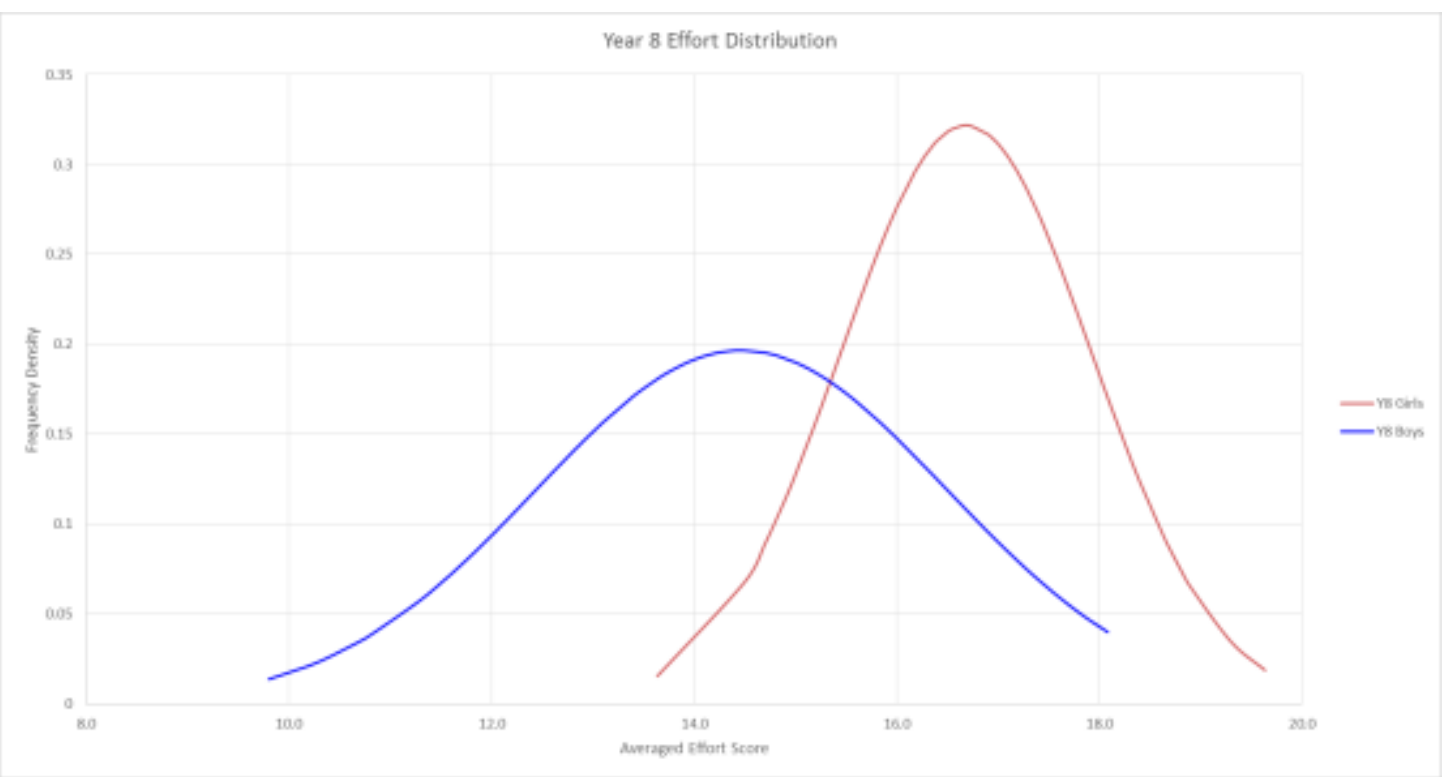

Figure 9b: Distribution of Year 8 Boys' and Girls' Effort Grades (Term 1, 2015). 
(2016). Tracking and visualizing student effort: Evolution of a practical analytics tool for staff and student engagement. Journal of Learning Analytics, 3(2), 165-192. http://dx.doi.org/10.18608/jla.2016.32.8

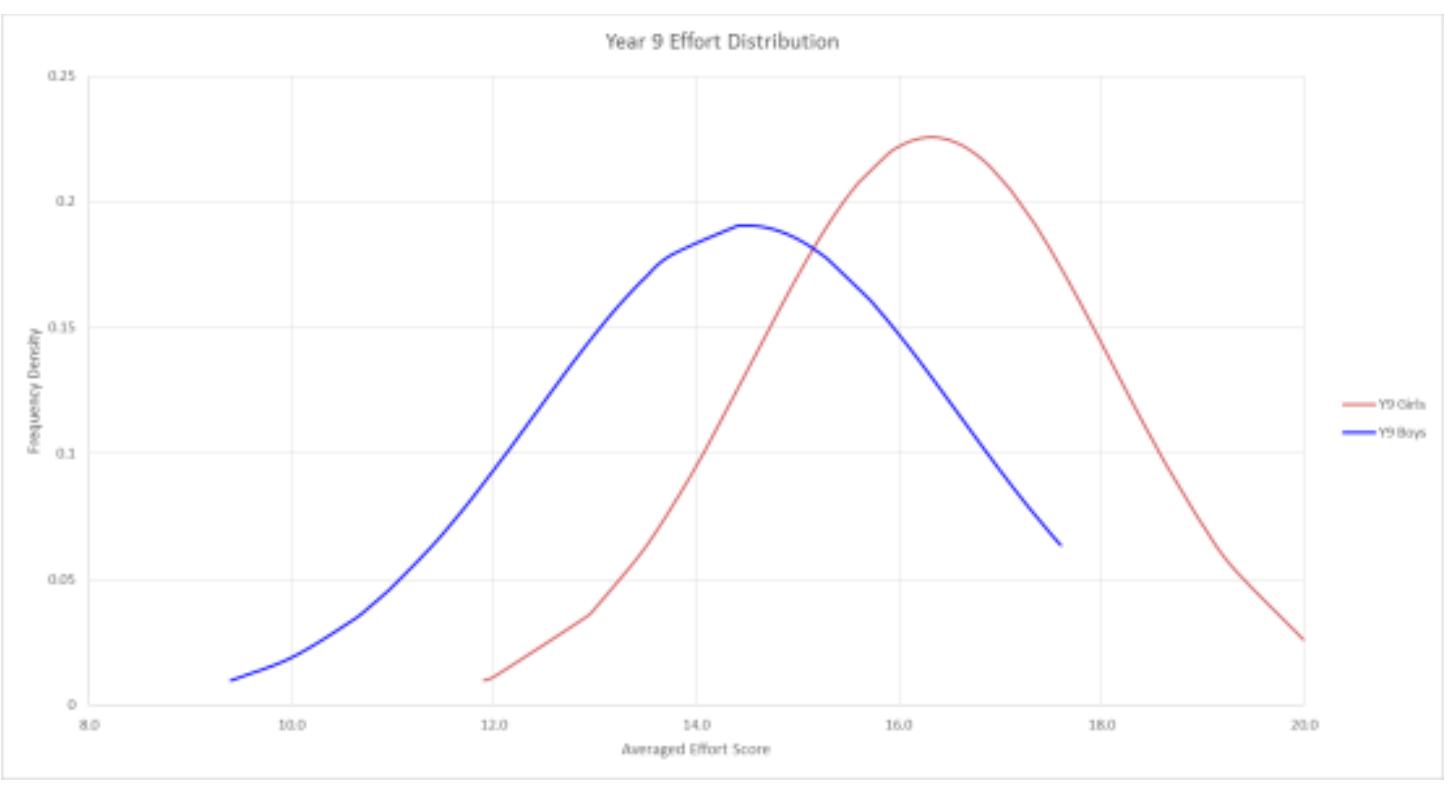

Figure 9c: Distribution of year 9 boys' and girls' effort grades (Term 1, 2015).

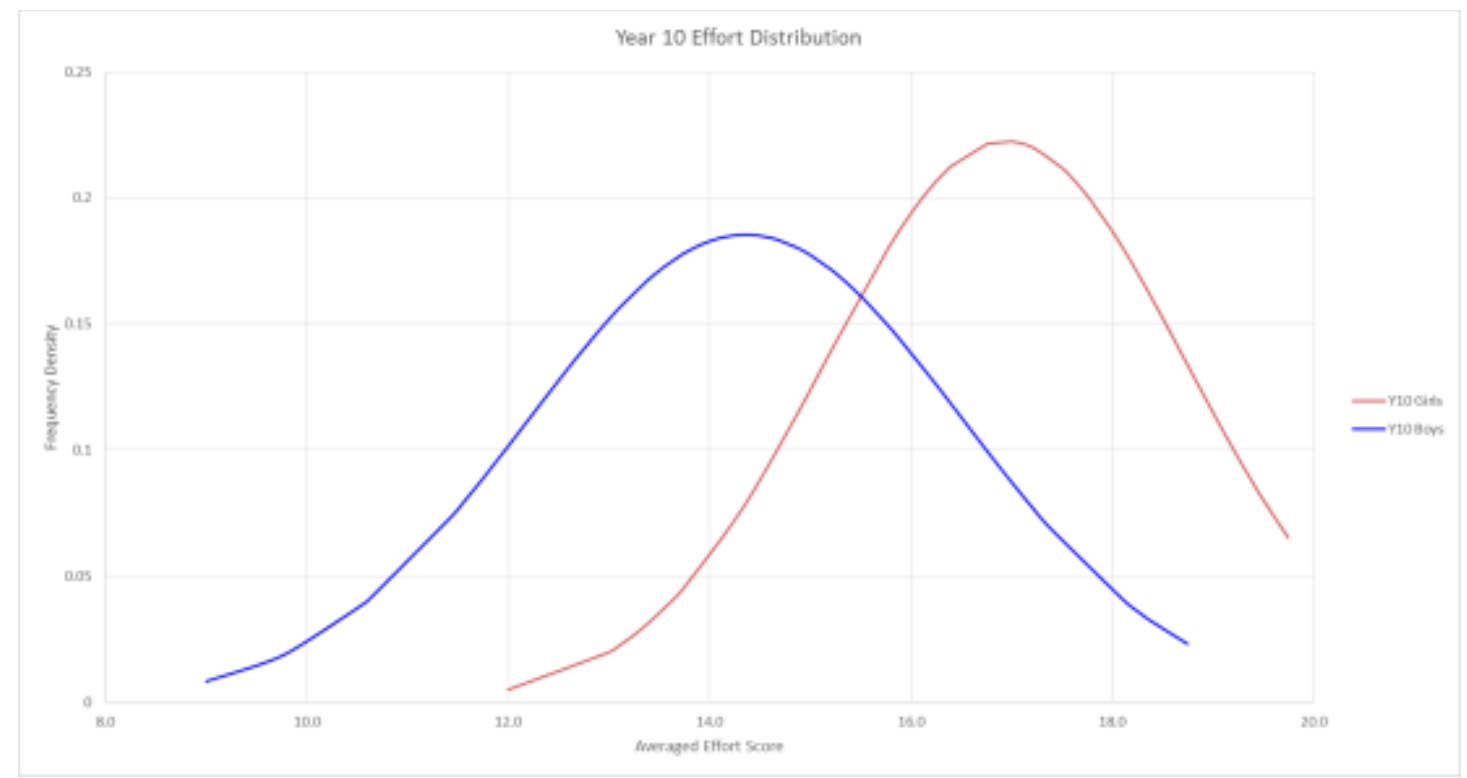

Figure 9d: Distribution of year 10 boys' and girls' effort grades (Term 1, 2015). 
(2016). Tracking and visualizing student effort: Evolution of a practical analytics tool for staff and student engagement. Journal of Learning Analytics, 3(2), 165-192. http://dx.doi.org/10.18608/jla.2016.32.8

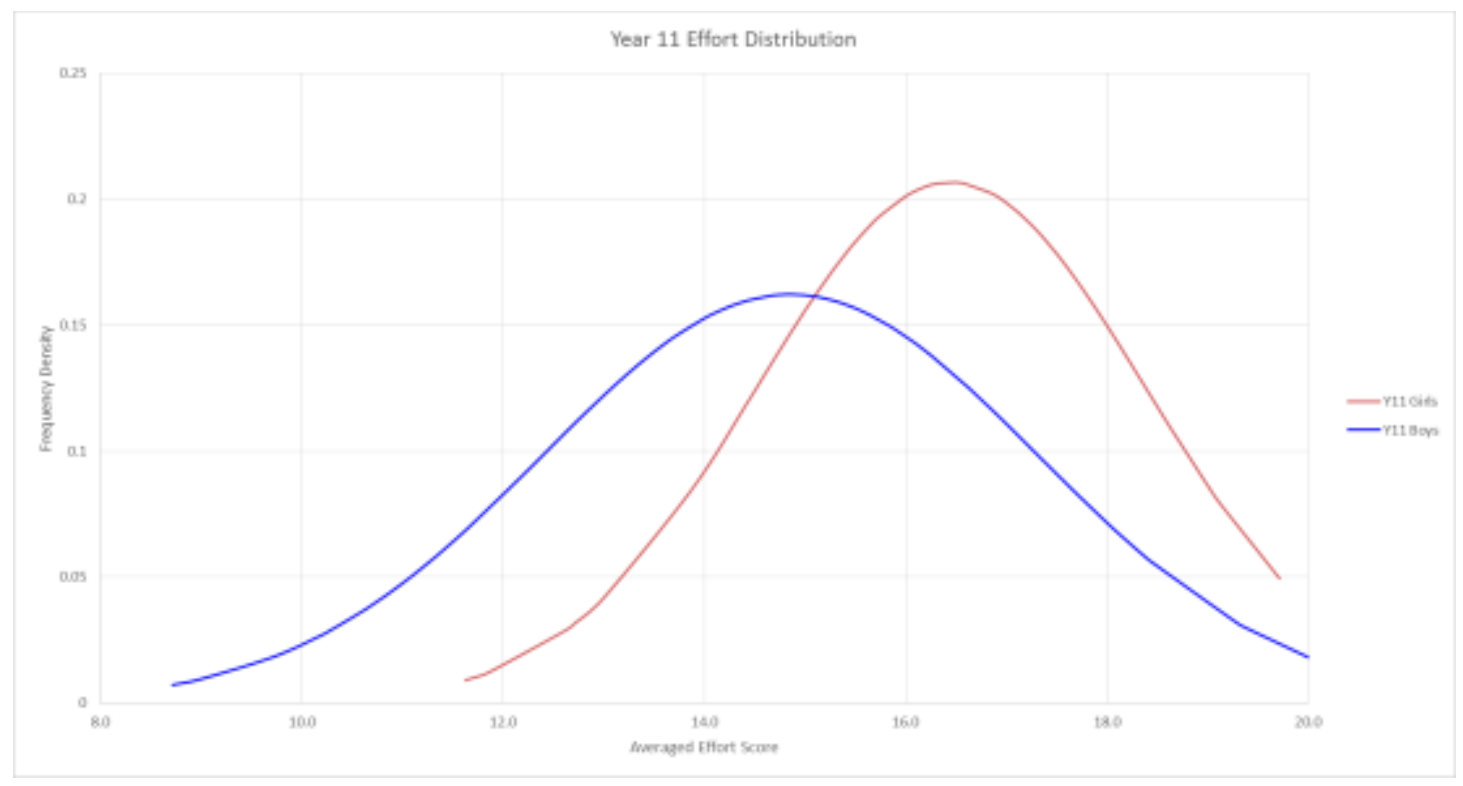

Figure 9e: Distribution of year 11 boys' and girls' effort grades (Term 1, 2015).

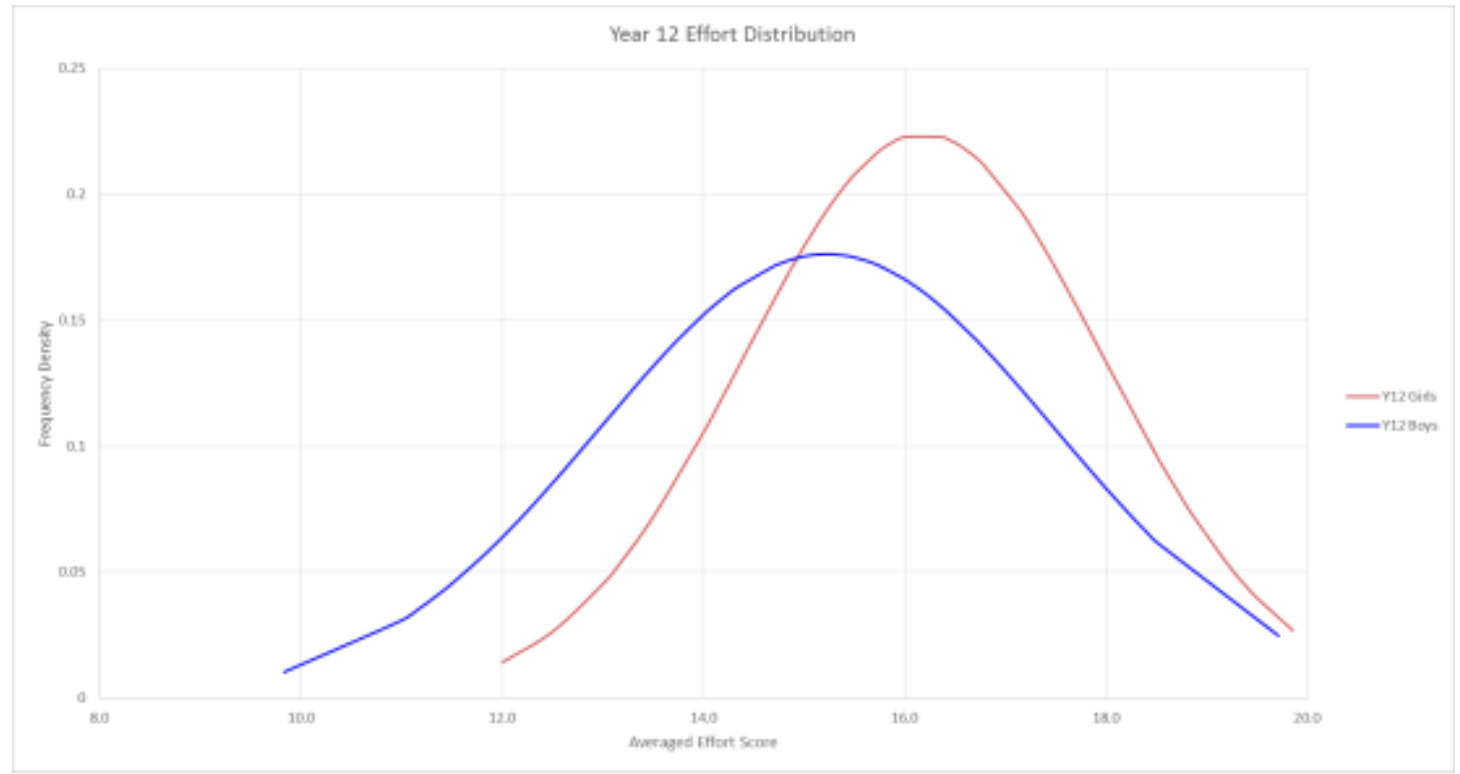

Figure 9f: Distribution of year 12 boys' and girls' effort grades (Term 1, 2015). 